\title{
THE IMPACT OF TAXES AND SOCIAL SPENDING ON INEQUALITY AND POVERTY IN ARGENTINA, BOLIVIA, BRAZIL, MEXICO, PERU AND URUGUAY: AN OVERVIEW
}

Nora Lustig, Florencia Amábile, Marisa Bucheli, George Gray Molina, Sean Higgins, Miguel Jaramillo, Wilson Jiménez Pozo, Veronica Paz Arauco, Claudiney Pereira, Máximo Rossi, John Scott, and Ernesto Yáñez Aguilar

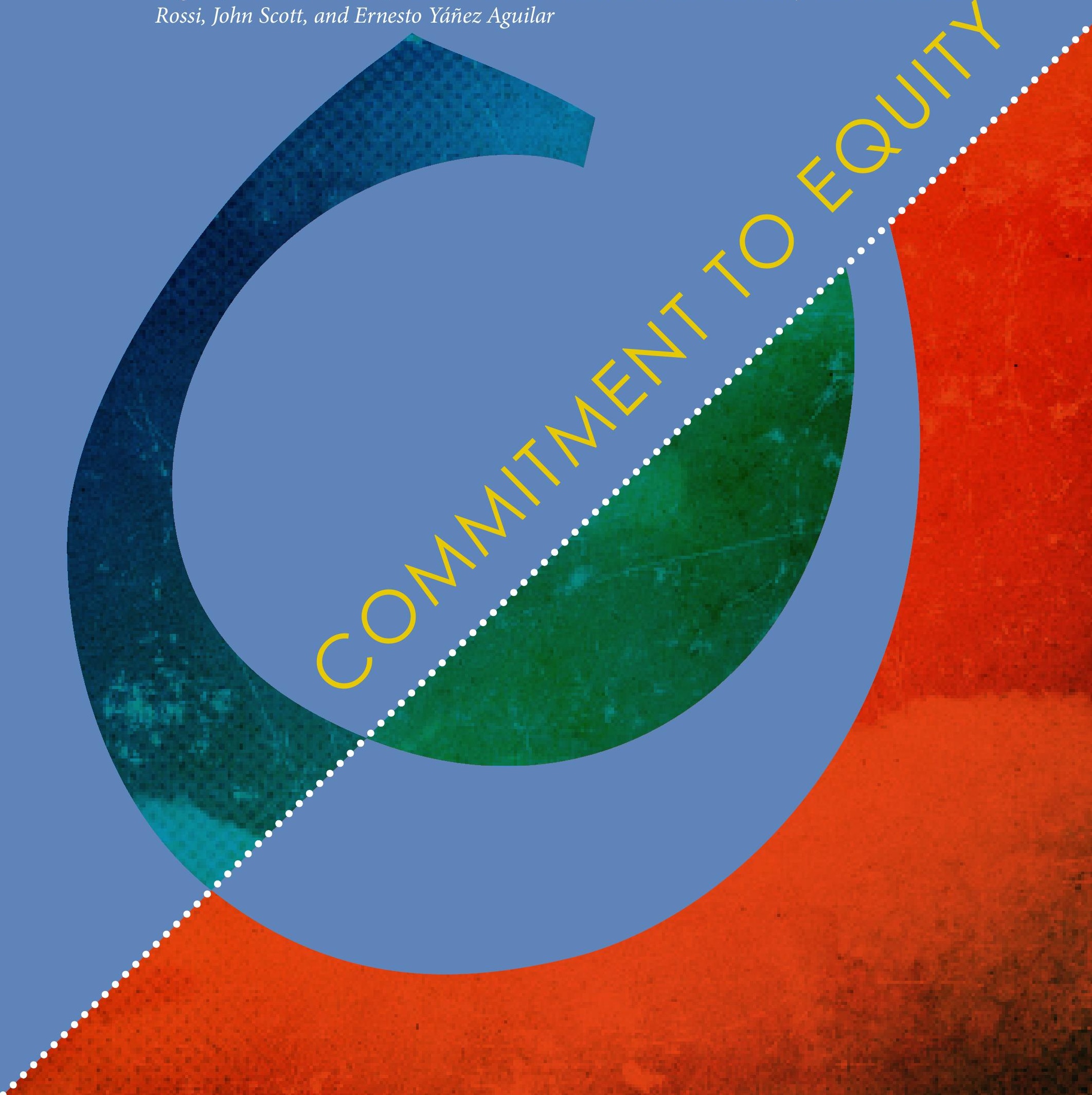


COMMITMENT TO EQUITY

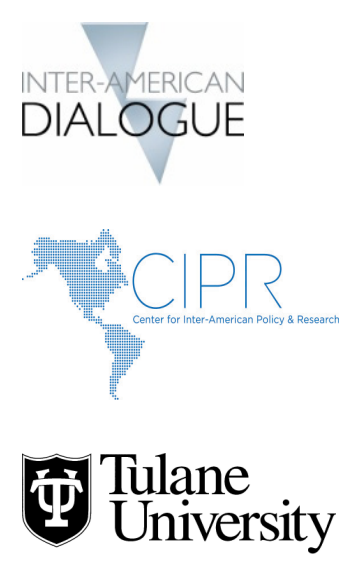

THE IMPACT OF TAXES AND SOCIAL SPENDING ON INEQUALITY AND POVERTY IN ARGENTINA, BOLIVIA, BRAZIL, MEXICO, PERU AND URUGUAY: AN OVERVIEW*

Lustig, Nora, Florencia Amábile, Marisa Bucheli, George Gray Molina, Sean Higgins, Miguel Jaramillo, Wilson Jiménez, Pozo, Veronica Paz, Arauco, Claudiney Pereira, Carola Pessino, Máximo Rossi, John Scott, and Ermesto Yáñez. Aguilar.'

CEQ Working Paper No. 13

APRIL 2013; REVISED AUGUST 2013

\section{ABSTRACT}

How much redistribution and poverty reduction is being accomplished in Latin America through social spending, subsidies, and taxes? Standard fiscal incidence analyses applied to Argentina, Bolivia, Brazil, Mexico, Peru, and Uruguay using a comparable methodology yields the following results. Direct taxes and cash transfers reduce inequality and poverty by nontrivial amounts in Argentina, Brazil, and Uruguay but less so in Bolivia, Mexico, and Peru. While direct taxes are progressive, the redistributive impact is small because direct taxes as a share of GDP are generally low. Cash transfers are quite progressive in absolute terms, except in Bolivia where programs are not targeted to the poor. In Bolivia and Brazil, indirect taxes more than offset the poverty-reducing impact of cash transfers. When one includes the in-kind transfers in education and health, valued at government costs, they reduce inequality in all countries by considerably more than cash transfers, reflecting their relative size.

Keywords: fiscal incidence, inequality, poverty, taxes, social spending, Latin America JEL Codes: H22, I3, $\mathrm{O} 1$

\footnotetext{
${ }^{1}$ Nora Lustig is Samuel Z. Stone Professor of Latin American Economics, Tulane University (Department of Economics; Stone Center for Latin American Studies and CIPR); nonresident fellow, Center for Global Development and Inter-American Dialogue. All other affiliations are available at www.commitmentoequity.org.
}

A condensed version of this paper will appear as the introduction to Lustig, Nora, Carola Pessino, and John Scott, editors, Fiscal Policy, Poverty and Redistribution in Latin America, Special Issue, Public Finance Review, forthcoming.

The values shown here may differ from those that appear in the working papers posted at www.commitmentoequity.org. If they differ, those included in this document take precedence as the most updated values.

The authors are very grateful to Dan Teles as well as to Nicole Florack and Juan Carlos Monterrey, for their excellent research assistantship in the preparation of this overview and the background papers. We also thank Samantha Greenspun, Emily Travis, and Dustin Wonnell who contributed to the project at various points in time. 


\section{INTRODUCTION}

Although inequality has been falling since 2000 (Lustig, López-Calva, and Ortiz-Juarez, 2013), Latin America is still one of the regions with the highest degree of inequality in the world (Ferreira and Ravallion, 2008). Poverty rates — although not the highest by far-are high for Latin America's GDP per capita (InterAmerican Development Bank, 2011, p. 43). Given these facts, the extent to which governments use their power to tax and spend to attenuate inequality and poverty is of great importance. ${ }^{2}$ This overview summarizes the results of applying standard benefit-tax incidence analysis to estimate the effect of direct taxes, indirect taxes and subsidies, and social spending (cash and in-kind transfers) on inequality and poverty in six countries: Argentina (Lustig and Pessino, forthcoming), Bolivia (Paz Arauco et al., forthcoming), Brazil (Higgins and Pereira, forthcoming), Mexico (Scott, forthcoming), Peru (Jaramillo, forthcoming), and Uruguay (Bucheli et al., forthcoming). It should be noted that the study for Argentina does not include the impact of taxes.

In this overview we discuss the broad characteristics of the methodology used in these papers and highlight the main results. All country studies apply a common methodology to microdata obtained from household surveys. The studies for Bolivia (2009), Brazil (2009), Peru (2009), and Uruguay (2009) focus on average incidence for a particular (recent) year. The studies for Argentina (2003, 2006, 2009) and Mexico (2008, 2010) look at how incidence has changed over a particular period of time. ${ }^{3}$ As is common in most benefittax incidence analyses, the studies do not model behavioral, lifecycle, or general equilibrium effects. Except in the case of Argentina, the analysis does not discuss the macroeconomic sustainability of taxation and social spending patterns either. Aside from these limitations (commonly found in other fiscal incidence studies as well), the studies are among the most detailed, comprehensive, and comparable tax-benefit incidence analyses available for Latin American countries to date, and there is full transparency when comparability is not strict. In addition, compared to some of the existing publications, reliance on secondary sources is kept to a minimum. ${ }^{4}$

\section{CONCEPTS, DEFINITIONS, AND DATA}

i Market, Net Market, Disposable, Post-fiscal, and Final Income: Definitions and Measurement

We use five income concepts in our incidence analyses: market, net market, disposable, post-fiscal, and final income. ${ }^{5}$ Market income ${ }^{6}$ is total current income before direct taxes, ${ }^{7}$ equal to the sum of gross (pre-tax)

2 See, for example, Birdsall, de la Torre, and Menezes (2008).

${ }^{3}$ Although the household survey in Argentina covers urban areas only, for the reasons explained in Lustig and Pessino (forthcoming), the analysis is taken to be representative for the whole country.

${ }^{4}$ Breceda, Rigolini, and Saavedra (2008) and, especially, Goñi, López, and Servén (2011) rely substantially on secondary sources for their incidence analysis.

${ }^{5}$ For more details on concepts and definitions, see Lustig and Higgins (2013).

${ }^{6}$ Market income is sometimes called primary income.

${ }^{7}$ Taxes include non-pension social security contributions in the benchmark analysis and all social security contributions in the 
wages and salaries in the formal and informal sectors (also known as earned income); income from capital (dividends, interest, profits, rents, etc.) in the formal and informal sectors (excludes capital gains and gifts); autoconsumption (except in the case of Argentina and Bolivia); ${ }^{8}$ imputed rent for owner-occupied housing; private transfers (remittances and other private transfers such as alimony); and old-age and other pensions from the contributory social security system. Net market income equals market income minus direct personal income taxes on all income sources (included in market income) that are subject to taxation and all contributions to social security except for the portion going towards pensions. ${ }^{9}$ Disposable income is equal to the sum of net market income plus direct government transfers (mainly cash transfers but can include food transfers). Post-fiscal income is defined as disposable income plus indirect subsidies minus indirect taxes (e.g., value added tax, sales tax, etc.). Final income is defined as post-fiscal income plus government in-kind transfers in the form of free or subsidized services in education, health, and housing minus co-payments or user fees. ${ }^{10}$ We also define final income* as disposable income plus government in-kind transfers in the form of free or subsidized services in education, health, and housing subsidies minus co-payments or user fees. The definitions are summarized in Diagram 1. For a detailed description of how each income concept was constructed in the six countries see the Statistical Appendix, available upon request. ${ }^{11}$

In the fiscal incidence literature, pensions from contributory systems have been sometimes treated as part of market income and other times as government transfers. Arguments exist both for treating contributory pensions as part of market income because they are deferred income (Breceda, Rigolini, and Saavedra, 2008; Immervoll et al., 2009) and for treating them as a government transfer, especially in systems with a large subsidized component (Goñi, López, and Servén, 2011; Immervoll et al., 2009; Lindert, Skoufias, and Shapiro, 2006; Silveira et al., 2011). Since this is an unresolved issue, in our study we defined a benchmark case in which contributory pensions are part of market income. We also performed a sensitivity analysis where pensions are classified under government transfers. ${ }^{12}$ The principal results presented here are for the benchmark analysis. An analysis of the effects of treating pensions as transfers is included at the end of this overview. More detailed results of this sensitivity analysis can be found in the Statistical Appendix, available upon request.

sensitivity analysis.

8 Argentina does not include a question on autoconsumption and in the case of Bolivia the results with autoconsumption are specious (e.g., Bolivia ends up with the same distribution of income as Uruguay and a lower rural poverty than Mexico) so we opted to not use them.

${ }_{9}^{9}$ Since here we are treating contributory pensions as part of market income, the portion of the contributions to social security going towards pensions is treated as "saving."

${ }^{10}$ One may also include participation costs such as transportation costs or foregone incomes because of use of time in obtaining benefits. In our study, they were not included.

11 The studies exclude corporate and international trade taxes, some spending categories (such as infrastructure investments including urban services and rural roads that benefit the poor), and other public goods.

12 Immervoll et al. (2009) do the analysis under these two scenarios as well. 


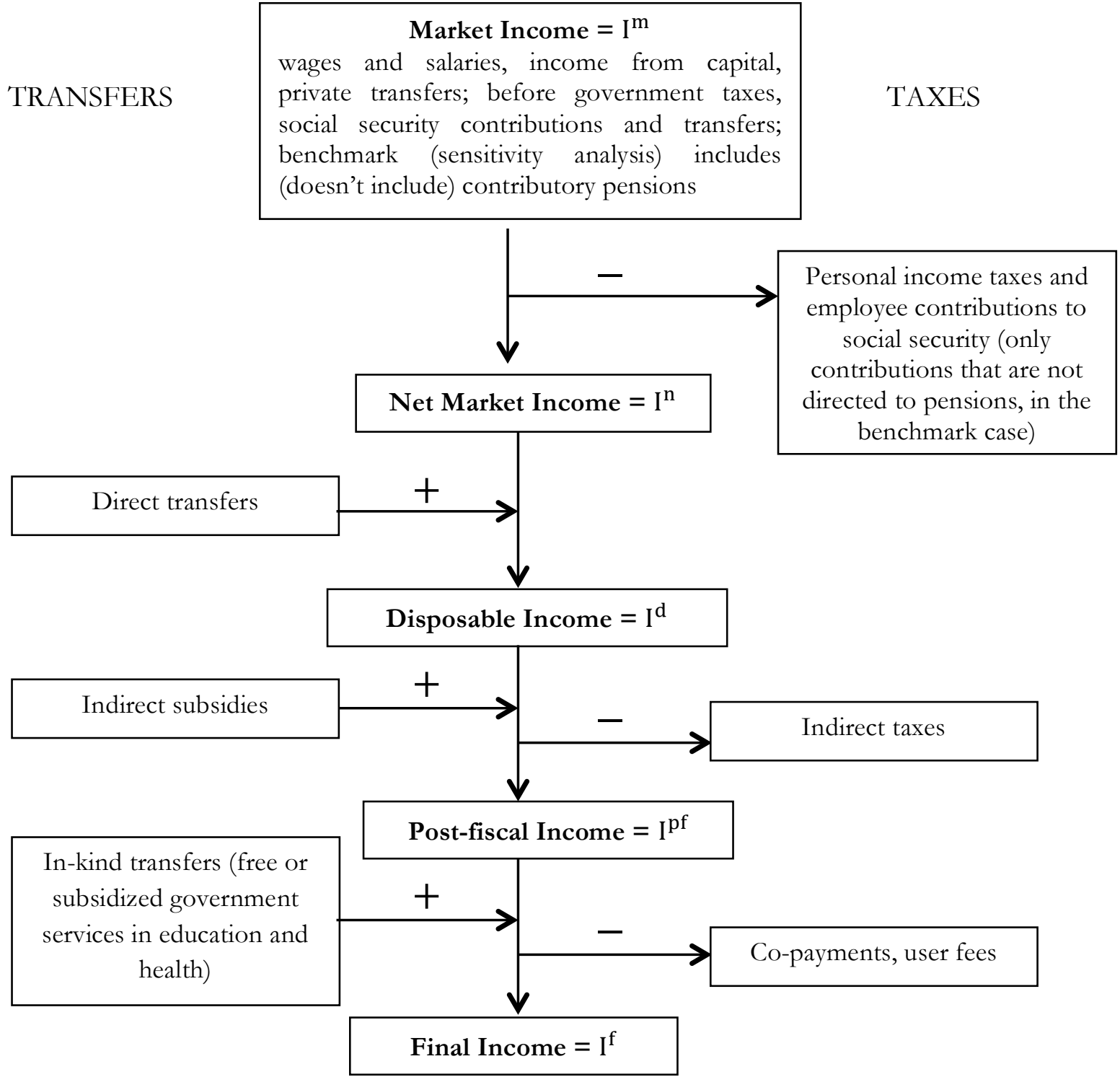

Source: Lustig and Higgins (2013).

Note: in some cases we also present results for "final income*" which is defined as disposable income plus in-kind transfers minus co-payments and user fees.

\section{ii Progressive and Regressive Revenues and Spending: Definitions}

To determine if a tax or transfer is progressive, concentration curves, concentration coefficients, and the Kakwani (1977) index or other measures are commonly used. In the fiscal incidence analysis literature, the terms "progressive" and "regressive" are used in two senses-which can be a cause of confusion. The progressivity/regressivity of a transfer can be measured in absolute terms, by comparing the amount of transfers across quantiles, or in relative terms, by comparing transfers as a percentage of the (pre-transfer) income of each quantile. In the tax incidence literature, where the fiscal application of the terms "progressive" and "regressive" originated, they are used exclusively in the relative sense. In the benefit (and 
tax-benefit) incidence literature, it is common practice to use the absolute as well as the relative concepts. ${ }^{13}$

Here, we define any transfer that is equalizing as progressive. This is consistent with the tax incidence literature and with an intuitively appealing principle: a transfer or tax is defined as progressive (regressive) if it results in a less (more) unequal distribution than that of market income. We then distinguish between progressive in absolute terms and progressive in relative terms.

It is important to note, however, that ranking programs in terms of degree of progressivity does not entail a ranking of their relative merits as redistributive instruments because there are other relevant characteristics to consider in a full comparative evaluation of redistributive efficiency such as coverage and behavioral effects.

\section{iii Tax Shifting Assumptions}

Consistent with other conventional tax incidence analyses, here we assume that the economic burden of direct personal income taxes is borne by the recipient of income. The burden of payroll and social security taxes is assumed to fall entirely on workers. Consumption taxes are assumed to be shifted forward to consumers. These assumptions are strong because, in essence, they imply that labor supply is perfectly inelastic and consumers have perfectly inelastic demands for goods and services. In practice they provide a reasonable approximation. ${ }^{14}$

Evasion of direct income and payroll taxes is taken into account in the analysis by assuming that individuals who do not participate in the contributory social security system do not pay income or payroll taxes (Brazil's survey includes a question on tax payments so tax evasion is assumed to be as reported in the survey). In the case of indirect (consumption) taxes, assumptions to take evasion into account varied. In Bolivia, it was assumed that purchases in informal sector establishments avoid indirect taxes both in urban and rural areas, but the rest of rural purchases include indirect taxes. In Brazil, the indirect tax rate for each type of good or service was obtained from a secondary source that estimated the effective rates taking into account evasion, but not the distribution of this evasion. In Mexico, it was assumed that all purchases in the rural areas and in informal sector urban establishments avoid indirect taxes, but the study also includes results of a sensitivity analysis assuming no informality in indirect taxes. In Peru, it was assumed that all purchases made in villages with no more than 100 households and in informal sector establishments, both urban and rural, avoid indirect taxes. In Uruguay, the legal rate of VAT was applied to every purchase regardless of place of purchases or region (rural vs. urban). For Brazil and Uruguay, this analysis may thus overestimate the impact

\footnotetext{
${ }^{13}$ Lindert, Skoufias, and Shapiro (2006), for example, define as progressive any transfer that is equalizing and distinguish between those that are progressive in absolute or relative terms. O’Donnell et al. (2008) also define as progressive any transfer that is equalizing but distinguish between weakly progressive (progressive in relative terms) and strongly progressive (progressive in absolute terms). Scott (2011) uses the term progressive only for transfers that are progressive in absolute terms; regressive transfers are those that are progressive only in relative terms (still equalizing) or outright regressive (unequalizing). Wagstaff (2012) uses the term "pro-poor" for transfers that are progressive in absolute terms and "pro-rich" for transfers that are progressive in relative terms (or outright regressive). Lambert (2002) uses opposite language. He defines as progressive (regressive) when relative transfers increase (decrease) with income because the proportion received increases (declines) with income. That is, Lambert chooses not to relate the concept of "progressive" with equalizing transfers.

${ }^{14}$ For example, Martinez-Vazquez (2008, p. 123) finds that “...the results obtained with more realistic and laborious assumptions on elasticities tend to yield quite similar results."
} 
and regressivity of indirect taxes, while for Mexico and Peru it might somewhat underestimate these effects. Taking into account informality in this analysis may also be more important in some countries than in others, depending on the actual extent of informality. Care must be taken in comparing the results for post-fiscal incomes.

\section{iv Incidence of Public Services}

The approach to estimate the incidence of public spending on education and health followed here is the socalled "benefit or expenditure incidence" or "government cost" approach. In essence, we use per beneficiary input costs obtained from administrative data as the measure of average benefits. This approach-also known as the "classic" or "nonbehavioral approach" — amounts to asking the following question: how much would the income of a household have to be increased if it had to pay for the free or subsidized public service at full cost?

\section{$\checkmark \quad$ Allocating Taxes and Transfers at the Household Level}

Information on direct and indirect taxes, transfers in cash and in-kind, and subsidies cannot always be obtained directly from household surveys. When it can be obtained, we call this the direct identification method. When the direct method is not feasible, one can use the inference, simulation, or imputation methods, or an alternate source. As a last resort, one can use secondary sources. The methods one can use to allocate taxes and transfers are described in detail in Lustig and Higgins (2013).

The specific method used for each category of taxes and transfers in each country study can be found in the Statistical Appendix, available upon request. The direct identification method was the method most frequently used, especially for cash transfers. Direct personal income taxes and indirect consumption taxes were simulated (including assumptions for evasion) in all cases except for direct taxes in Brazil. In-kind transfers were imputed using the government cost approach.

\section{vi Redistributive Effectiveness Indicator}

The effectiveness indicator is defined as the effect on inequality or poverty of the transfers being analyzed divided by their size relative to GDP. Although the size of transfers is measured by budget size according to national accounts, only transfer programs that are used in the incidence analysis are included, since by definition they are the only programs that can lead to a change in income observed in the data. For example, for direct transfers, the effectiveness indicator is the reduction between the net market income and disposable income Ginis (or any other inequality or poverty indicator) as a percent of the net market income Gini (or any other inequality or poverty indicator), divided by the size of direct transfers (only those included in the incidence analysis) as a percent of GDP. For total social spending, the effectiveness indicator is the reduction between the net market income and final income* Ginis (or any other inequality or poverty indicator) as a percent of the net market income Gini (or any other inequality or poverty indicator), divided by the size of total social spending (only direct cash and indirect in-kind transfers included in the incidence analysis) as a percent of GDP. 


\section{MAIN RESULTS}

How much redistribution and poverty reduction is being accomplished in each country through social spending, subsidies, and taxes? How progressive are revenue collection and government spending? What are the factors that limit the redistributive and poverty-reducing power of taxes and spending?

\section{i Inequality and Poverty Reduction}

Taxes and cash transfers reduce inequality and poverty by nontrivial amounts in Argentina ${ }^{15}$ and Uruguay, less so in Mexico and little in Peru. In the case of Bolivia, inequality remains essentially the same, but postfiscal extreme and moderate poverty increase with respect to market income. In Brazil, inequality falls significantly, but poverty rises (Figures 1 and 2, Table 1).

\section{FIGURE 1. GINI COEFFICIENT FOR EACH INCOME CONCEPT}

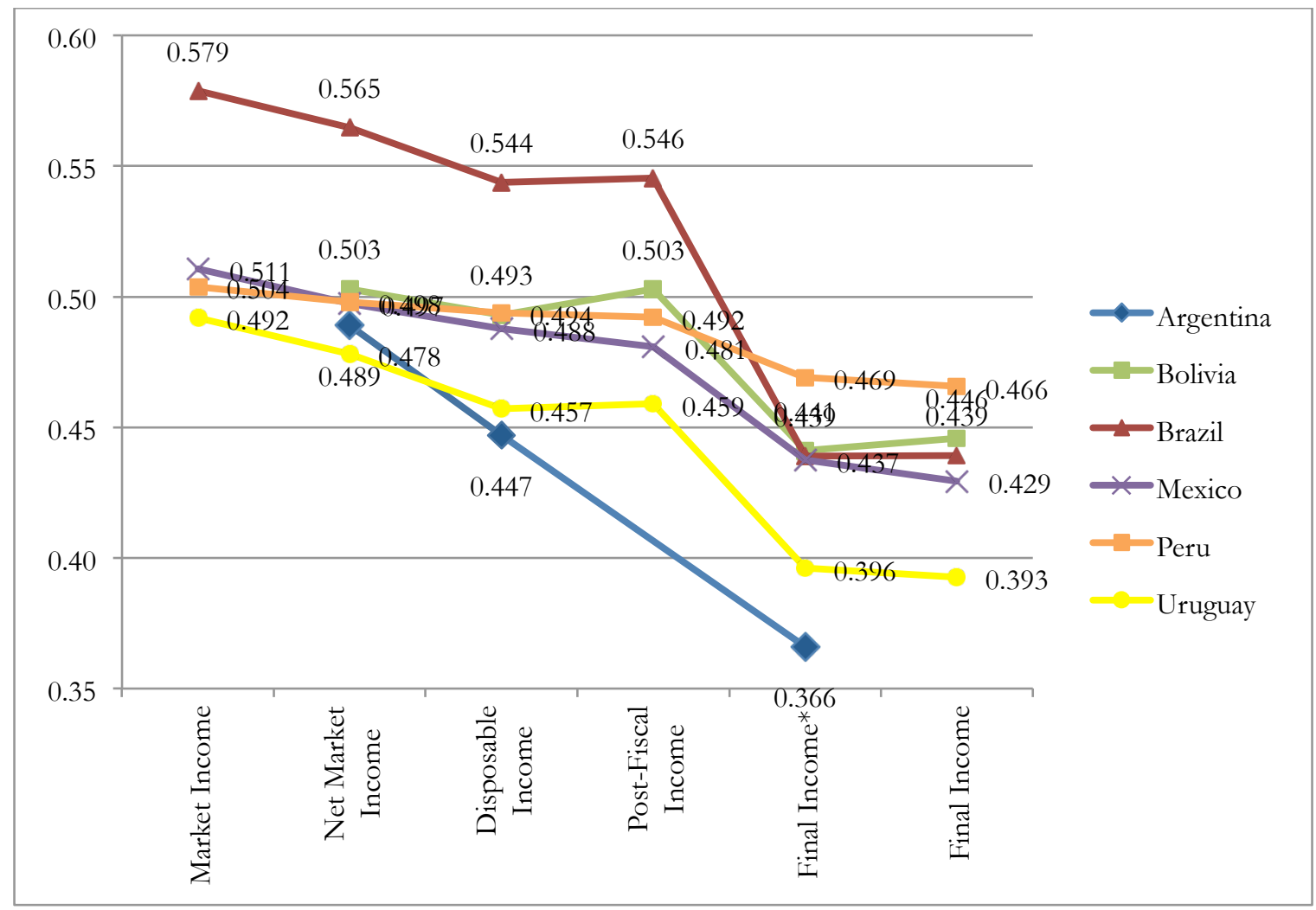

Argentina: Lustig and Pessino (forthcoming); Bolivia: Paz Arauco et al. (forthcoming); Brazil: Higgins and Pereira (forthcoming); Mexico: Scott (forthcoming); Peru: Jaramillo (forthcoming); and Uruguay: Bucheli et al. (forthcoming).

Notes:

a. For definition of income concepts see Diagram 1 and text.

b. The analysis for Argentina does not include the tax side so Disposable Income Gini is gross of direct personal income taxes. The results are thus not strictly comparable.

15 In the case of Argentina, only transfers are examined in the incidence analysis. 
FIGURE 2. EXTREME POVERTY HEADCOUNT RATIO FOR EACH INCOME CONCEPT

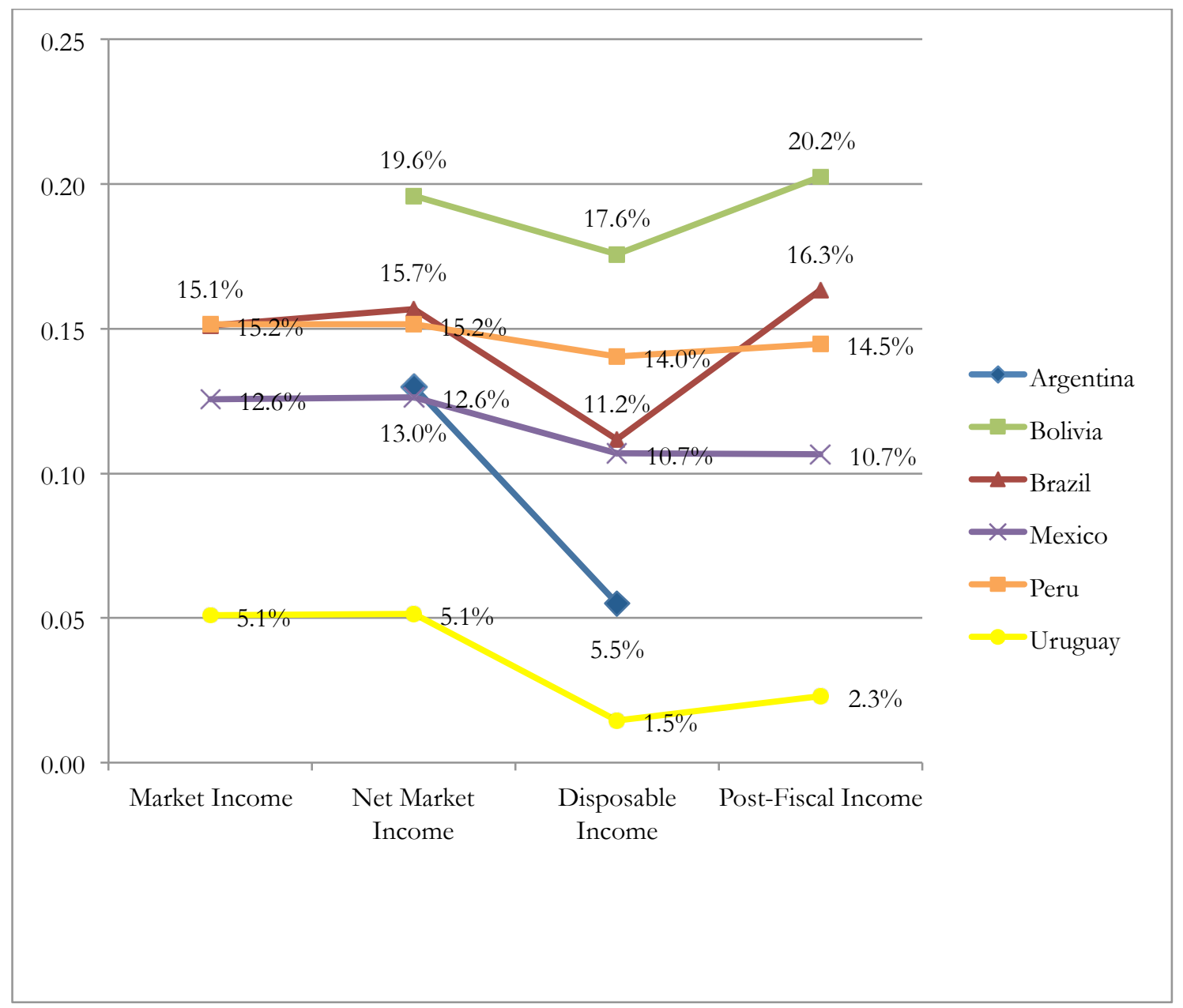

Argentina: Lustig and Pessino (forthcoming); Bolivia: Paz Arauco et al. (forthcoming); Brazil: Higgins and Pereira (forthcoming); Mexico: Scott (forthcoming); Peru: Jaramillo (forthcoming); and Uruguay: Bucheli et al. (forthcoming).

Notes:

a. For definition of income concepts see Diagram 1 and text.

b. The analysis for Argentina does not include the tax side so Disposable Income Headcount is gross of direct personal income taxes. The results are thus not strictly comparable. 
TABLE 1. REDUCTION IN POVERTY AND INEQUALITY AND EFFECTIVENESS

\begin{tabular}{|c|c|c|c|c|c|}
\hline & $\begin{array}{lr}\% \text { Change in } \\
\text { Net Market } \\
\text { Incomer wrt } \\
\text { Market } \\
\text { Income } \\
\end{array}$ & $\begin{array}{l}\% \text { Change in } \\
\text { Disposable } \\
\text { Income wrt } \\
\text { Market } \\
\text { Income }\end{array}$ & $\begin{array}{l}\% \text { Change in } \\
\text { Post-Fiscal } \\
\text { Income wrt } \\
\text { Market Income } \\
\text { a }\end{array}$ & $\begin{array}{l}\% \text { Change in } \\
\text { Final Income* } \\
\text { wrt Market } \\
\text { Income }\end{array}$ & $\begin{array}{l}\% \text { Change in } \\
\text { Final Income } \\
\text { wrt Market } \\
\text { Income }\end{array}$ \\
\hline \multicolumn{6}{|l|}{ Argentina (2009) ${ }^{\mathrm{b}}$} \\
\hline Gini & - & $-8.6 \%$ & - & $-25.2 \%$ & - \\
\hline Effectiveness Indicator & - & 2.3 & - & 2.1 & - \\
\hline \multicolumn{6}{|l|}{ Headcount index $(\%)$} \\
\hline$\$ 2.50 \mathrm{PPP} /$ day & - & $-57.7 \%$ & - & - & - \\
\hline Effectiveness Indicator & - & 15.6 & - & - & - \\
\hline \multicolumn{6}{|l|}{ Bolivia $(2009)^{c}$} \\
\hline Gini &.-- & $-2.0 \%$ & $-0.04 \%$ & $-12.4 \%$ & $-11.3 \%$ \\
\hline Effectiveness Indicator &.-- & 1.0 & na & 0.9 & na \\
\hline \multicolumn{6}{|l|}{ Headcount index (\%) } \\
\hline$\$ 2.50 \mathrm{PPP} /$ day &.-- & $-10.4 \%$ & $3.3 \%$ &.-- &.-- \\
\hline Effectiveness Indicator &.-- & 5.1 & na &.-- &.-- \\
\hline \multicolumn{6}{|l|}{ Brazil (2009) } \\
\hline Gini & $-2.4 \%$ & $-6.0 \%$ & $-5.7 \%$ & $-24.1 \%$ & $-24.1 \%$ \\
\hline Effectiveness Indicator &.-- & 0.9 & na & 1.7 & na \\
\hline \multicolumn{6}{|l|}{ Headcount index (\%) } \\
\hline$\$ 2.50 \mathrm{PPP} /$ day & $3.8 \%$ & $-26.1 \%$ & $8.1 \%$ &.-- &.-- \\
\hline Effectiveness Indicator &.-- & 6.9 & na &.-- &.-- \\
\hline \multicolumn{6}{|l|}{ Mexico (2010) } \\
\hline Gini & $-2.6 \%$ & $-4.5 \%$ & $-5.8 \%$ & $-14.4 \%$ & $-15.9 \%$ \\
\hline Effectiveness Indicator &.-- & 2.1 & na & 1.4 & na \\
\hline \multicolumn{6}{|l|}{ Headcount index (\%) } \\
\hline$\$ 2.50 \mathrm{PPP} /$ day & $0.6 \%$ & $-14.9 \%$ & $-15.1 \%$ &.-- &.-- \\
\hline Effectiveness Indicator &.-- & 16.0 & na &.-- &.-- \\
\hline \multicolumn{6}{|l|}{ Peru (2009) } \\
\hline Gini & $-1.1 \%$ & $-2.0 \%$ & $-2.4 \%$ & $-6.9 \%$ & $-7.6 \%$ \\
\hline Effectiveness Indicator &.-- & 2.4 & na & 1.2 & na \\
\hline \multicolumn{6}{|l|}{ Headcount index (\%) } \\
\hline$\$ 2.50 \mathrm{PPP} /$ day & $0.0 \%$ & $-7.3 \%$ & $-4.4 \%$ &.-- &.-- \\
\hline Effectiveness Indicator &.-- & 20.1 &.-- &.-- &.-- \\
\hline \multicolumn{6}{|l|}{ Uruguay (2009) } \\
\hline Gini & $-2.8 \%$ & $-7.1 \%$ & $-6.7 \%$ & $-19.6 \%$ & $-20.2 \%$ \\
\hline Effectiveness Indicator &.-- & 1.9 & na & 1.6 & na \\
\hline \multicolumn{6}{|l|}{ Headcount index (\%) } \\
\hline$\$ 2.50 \mathrm{PPP} /$ day & $0.7 \%$ & $-71.5 \%$ & $-54.1 \%$ &.-- &.-- \\
\hline Effectiveness Indicator &.-- & 31.7 & na &.-- & $\begin{array}{c}-- \\
\end{array}$ \\
\hline
\end{tabular}

Argentina: Lustig and Pessino (forthcoming); Bolivia: Paz Arauco et al. (forthcoming); Brazil: Higgins and Pereira (forthcoming); 
Mexico: Scott (forthcoming); Peru: Jaramillo (forthcoming); and Uruguay: Bucheli et al. (forthcoming).

Notes:

For definition of income concepts see Diagram 1 and text.

"na": not applicable because these values combine the redistributive effects of taxes and transfers

a. "wrt" is an abbreviation for "with respect to."

b. The Argentine study does not analyze the tax side of the fiscal system; hence, percent change is calculated with respect to net market income and results are not strictly comparable for the change in disposable income.

c. In Bolivia direct income taxes are almost nil (for example, personal income is not taxed) and the study does not include them. As such, the percent change is calculated with respect to net market income.

Direct taxes and cash transfers reduce inequality (as measured by the Gini coefficient and with respect to market income inequality) by as much as 8.6 percent in Argentina (even without including direct taxes) and 7.1 percent in Uruguay to as little as 2 percent in Bolivia and Peru. In Brazil and Uruguay, the reduction in disposable income inequality is mainly due to the impact of cash transfers. In Peru the little redistribution that there is comes from both direct taxes (1.1 percent) and transfers ( 0.9 percent), while in Bolivia (which has practically no personal income taxes) it is solely from cash transfers.

Net indirect taxes temper the redistributive impact of the fiscal system in Bolivia, Brazil, and Uruguay but not in Mexico or Peru. When one adds the effect of transfers in-kind (access to free or quasi-free services in education and health), inequality declines substantially in all countries, ranging from 25.2 percent, 24.1 percent, and 20.2 percent in Argentina, Brazil, and Uruguay, respectively, to 7.6 percent in Peru. Argentina achieves this effect by the size as well as the redistributive effectiveness of its social spending. Brazil has a lower level of effectiveness, similar to Mexico and Peru; the large differences in terms of impact among the three countries are explained mainly by the size of social spending. Finally, despite spending considerably less than Bolivia and not much more than Mexico, Uruguay is highly effective at reducing inequality and poverty. 
FIGURE 3. REDUCTION IN INEQUALITY WITH RESPECT TO MARKET INCOME GINI COEFFICIENT, SOCIAL SPENDING, AND REDISTRIBUTIVE EFFECTIVENESS

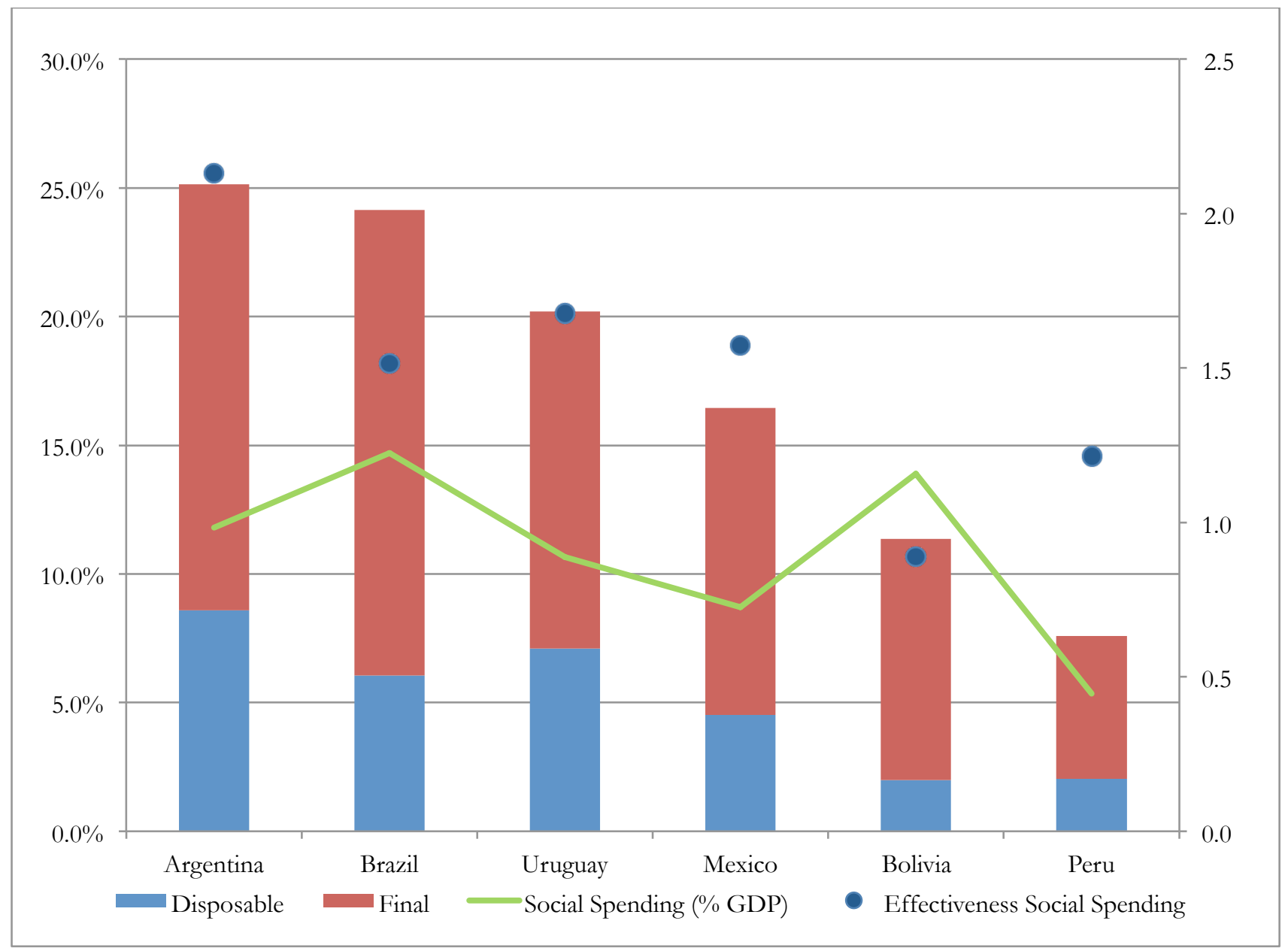

Argentina: Lustig and Pessino (forthcoming); Bolivia: Paz Arauco et al. (forthcoming); Brazil: Higgins and Pereira (forthcoming); Mexico: Scott (forthcoming); Peru: Jaramillo (forthcoming); and Uruguay: Bucheli et al. (forthcoming).

Notes:

a. Effectiveness measured on right-hand axis.

b. For Argentina the change is with respect to net market income and final is final income*; that is, the impact of direct and indirect taxes (and indirect subsidies) was not taken into account so the indicators are not strictly comparable with the others. 
Poverty is measured for market, net market, disposable, and post-fiscal income only since the poverty lines are defined without considering the income in-kind stemming from access to free education and health services. Here we report the impact of taxes and benefits on extreme poverty measured by the proportion of the population with incomes below the international poverty line of $\$ 2.50 \mathrm{PPP}$ per day. Cash transfers have quite a heterogeneous impact on poverty depending on the country, ranging from a decline (with respect to market income) of 71.5 percent in Uruguay to 7.3 percent in Peru. Indirect taxes more than offset the effect of cash transfers on poverty in Bolivia and Brazil.

A word of caution is in order. The indicators of inequality and poverty have some comparability issues for two main reasons. First, the assumptions to take into account indirect tax evasion differ across countries, as described above (section 2.3). Second, Peru and Uruguay did not include the impact of indirect subsidies in the incidence analysis. Also, as stated above, Argentina is not strictly comparable with the rest because the study focuses only on the spending side.

\section{ii Size of Budget: Government Primary Spending as a Share of GDP}

Table 2 presents taxes and spending as a share of GDP and identifies which taxes and transfer programs were included in the incidence analysis. As noted by Lustig et al. (2012), one cannot really speak of a "Latin American" prototype. As one can see, the six countries are quite heterogeneous in terms of government size as well as spending and revenue-collection patterns. Government spending as a share of GDP in Argentina and Brazil, for example, is similar to that found in OECD countries while in Mexico and Peru, the ratios are half as large. Thus, in the cases of Argentina and Brazil—and to a lesser extent in Bolivia and Uruguay-the size of the government budget is not a constraint on redistributive and poverty-reducing interventions. In the cases of Mexico and Peru, raising enough revenue to increase social spending as a percentage of GDP would be a relevant option. 
TABLE 2. GOVERNMENT SPENDING AND REVENUE BY CATEGORY IN PUBLIC ACCOUNTS AND INCIDENCE ANALYSIS (AS A PERCENT OF GDP)

\begin{tabular}{|c|c|c|c|c|c|c|c|c|c|c|c|c|}
\hline \multirow{3}{*}{$\begin{array}{l}\begin{array}{l}\text { Government Spending } \\
\text { Revenue (as a \% of GDP) }\end{array} \\
\begin{array}{l}\text { Gross National Income } \\
\text { capita (PPP US\$) }\end{array}\end{array}$} & \multicolumn{2}{|c|}{$\begin{array}{l}\text { Argentina } \\
(2009)\end{array}$} & \multicolumn{2}{|c|}{ Bolivia (2009) } & \multicolumn{2}{|c|}{ Brazil (2009) } & \multicolumn{2}{|c|}{ Mexico (2010) } & \multicolumn{2}{|c|}{ Peru (2009) ${ }^{m}$} & \multicolumn{2}{|c|}{ Uruguay (2009) } \\
\hline & Total & $\mathbf{I A}^{\mathrm{a}}$ & Total & $\mathbf{I A}^{\mathbf{a}}$ & Total & $\mathbf{I A}^{\mathrm{a}}$ & Total & $\mathbf{I A}^{\mathrm{a}}$ & Total & $\mathbf{I A}^{\mathrm{a}}$ & Total & $\mathbf{I A}^{\mathrm{a}}$ \\
\hline & 14,230 & & 3,919 & & 10,140 & & 14,390 & & 8,390 & & 12,412 & \\
\hline Total Government Spending ${ }^{\mathrm{b}}$ & $43.2 \%$ & & $34.8 \%$ & & $51.2 \%$ & & $25.7 \%$ & & $25.5 \%$ & & $30.8 \%$ & \\
\hline Primary Government Spending ${ }^{c}$ & $40.6 \%$ & & $33.3 \%$ & & $41.4 \%$ & & $23.7 \%$ & & $24.2 \%$ & & $27.9 \%$ & \\
\hline Social Spending ${ }^{\mathrm{d}}$ & $20.6 \%$ & $11.8 \%$ & $14.7 \%$ & $13.9 \%$ & $16.2 \%$ & $14.7 \%$ & $10.0 \%$ & $8.7 \%$ & $8.4 \%$ & $4.8 \%$ & $13.0 \%$ & $10.6 \%$ \\
\hline Total Cash Transfers & $3.7 \%$ & $3.7 \%$ & $2.0 \%$ & $2.0 \%$ & $4.2 \%$ & $4.2 \%$ & $1.0 \%$ & $1.0 \%$ & $0.4 \%$ & $0.4 \%$ & $2.3 \%$ & $2.3 \%$ \\
\hline $\begin{array}{l}\text { Cash Transfers (excluding all } \\
\text { Pensions) }\end{array}$ & $0.8 \%$ & $0.8 \%$ & $0.7 \%$ & $0.7 \%$ & $3.7 \%$ & $3.7 \%$ & $0.8 \%$ & $0.8 \%$ & $0.4 \%$ & $0.4 \%$ & $1.7 \%$ & $1.7 \%$ \\
\hline Noncontributory Pensions e & $2.9 \%$ & $2.9 \%$ & $1.4 \%$ & $1.4 \%$ & $0.5 \%$ & $0.5 \%$ & $0.2 \%$ & $0.2 \%$ & $0.0 \%$ & $0.0 \%$ & $0.5 \%$ & $0.5 \%$ \\
\hline Total In-kind Transfers ${ }^{f}$ & $12.9 \%$ & $8.1 \%$ & $11.9 \%$ & $11.9 \%$ & $10.5 \%$ & $10.5 \%$ & $7.7 \%$ & $7.7 \%$ & $5.9 \%$ & $4.4 \%$ & $8.4 \%$ & $8.4 \%$ \\
\hline Education & $6.7 \%$ & $5.6 \%$ & $8.3 \%$ & $8.3 \%$ & $5.3 \%$ & $5.3 \%$ & $4.5 \%$ & $4.5 \%$ & $2.8 \%$ & $2.1 \%$ & $3.7 \%$ & $3.7 \%$ \\
\hline of which Tertiary & $1.3 \%$ & $1.3 \%$ & $3.7 \%$ & $3.7 \%$ & $0.8 \%$ & $0.8 \%$ & $0.8 \%$ & $0.8 \%$ & $0.6 \%$ & $0.4 \%$ & $0.8 \%$ & $0.8 \%$ \\
\hline Health & $6.2 \%$ & $2.6 \%$ & $3.6 \%$ & $3.6 \%$ & $5.2 \%$ & $5.2 \%$ & $3.1 \%$ & $3.1 \%$ & $3.1 \%$ & $2.3 \%$ & $4.7 \%$ & $4.7 \%$ \\
\hline Contributory $g$ & $3.6 \%$ & $0.0 \%$ & $1.7 \%$ & $1.7 \%$ & $0.0 \%$ & $0.0 \%$ & $1.7 \%$ & $1.7 \%$ & $1.2 \%$ & $1.1 \%$ & $2.3 \%$ & $2.3 \%$ \\
\hline Noncontributory & $2.6 \%$ & $2.6 \%$ & $1.9 \%$ & $1.9 \%$ & $5.2 \%$ & $5.2 \%$ & $1.3 \%$ & $1.3 \%$ & $1.9 \%$ & $1.2 \%$ & $2.4 \%$ & $2.4 \%$ \\
\hline Other Social Spending & $4.0 \%$ & $0.0 \%$ & $0.8 \%$ & $0.0 \%$ & $1.5 \%$ & $0.0 \%$ & $1.3 \%$ & $0.0 \%$ & $2.1 \%$ & $0.0 \%$ & $2.3 \%$ & $0.0 \%$ \\
\hline Non-Social Spending ${ }^{\mathrm{h}}$ & $12.8 \%$ & $0.0 \%$ & $15.0 \%$ & $0.6 \%$ & $16.1 \%$ & $0.1 \%$ & $11.1 \%$ & $1.4 \%$ & $14.9 \%$ & $0.0 \%$ & $6.3 \%$ & $0.0 \%$ \\
\hline Indirect Subsidies & $5.6 \%$ & $0.0 \%$ & $0.6 \%$ & $0.6 \%$ & $0.1 \%$ & $0.1 \%$ & $1.4 \%$ & $1.4 \%$ & $\mathrm{na}^{\mathrm{n}}$ & $0.0 \%$ & $0.0 \%$ & $0.0 \%$ \\
\hline Other Non-Social Spending ${ }^{\mathrm{i}}$ & $7.2 \%$ & $0.0 \%$ & $14.4 \%$ & $0.0 \%$ & $16.0 \%$ & $0.0 \%$ & $9.7 \%$ & $0.0 \%$ & $14.9 \%$ & $0.0 \%$ & $6.3 \%$ & $0.0 \%$ \\
\hline Contributory Pensions i & $7.2 \%$ & $7.2 \%$ & $3.5 \%$ & $3.5 \%$ & $9.1 \%$ & $9.1 \%$ & $2.6 \%$ & $4.0 \%$ & $0.9 \%$ & $0.9 \%$ & $8.7 \%$ & $8.7 \%$ \\
\hline Debt Servicing & $2.6 \%$ & $0.0 \%$ & $1.6 \%$ & $0.0 \%$ & $9.8 \%$ & $0.0 \%$ & $2.0 \%$ & $0.0 \%$ & $1.3 \%$ & $0.0 \%$ & $2.9 \%$ & $0.0 \%$ \\
\hline Total Revenue & $41.0 \%$ & & $31.6 \%$ & & $44.0 \%$ & & $22.6 \%$ & & $24.0 \%$ & & $28.8 \%$ & \\
\hline Taxes $^{k}$ & $31.4 \%$ &.-- & $26.9 \%$ & $11.1 \%$ & $34.4 \%$ & $25.2 \%$ & $11.8 \%$ & $8.9 \%$ & $16.0 \%$ & $8.7 \%$ & $27.0 \%$ & $15.0 \%$ \\
\hline Direct Taxes & $8.1 \%$ &.-- & $5.7 \%$ & $0.0 \%$ & $12.2 \%$ & $4.2 \%$ & $5.2 \%$ & $2.3 \%$ & $5.0 \%$ & $1.5 \%$ & $4.7 \%$ & $4.7 \%$ \\
\hline Personal Income Tax & $1.7 \%$ &.-- & $0.2 \%$ & $0.0 \%$ & $2.1 \%$ & $2.1 \%$ & $2.3 \%$ & $2.3 \%$ & $1.5 \%$ & $1.5 \%$ & $4.7 \%$ & $4.7 \%$ \\
\hline Corporate Income Tax & $3.0 \%$ &.-- & $4.5 \%$ & $0.0 \%$ & $3.9 \%$ & $0.0 \%$ & $2.9 \%$ & $0.0 \%$ & $2.9 \%$ & $0.0 \%$ & $0.0 \%$ & $0.0 \%$ \\
\hline Other Direct Taxes & $3.4 \%$ &.-- & $1.0 \%$ & $0.0 \%$ & $6.2 \%$ & $2.1 \%$ & $0.0 \%$ & $0.0 \%$ & $0.6 \%$ & $0.0 \%$ & $0.0 \%$ & $0.0 \%$ \\
\hline $\begin{array}{l}\text { VAT and Other Indirect } \\
\text { Taxes }\end{array}$ & $12.8 \%$ &.-- & $11.1 \%$ & $11.1 \%$ & $15.2 \%$ & $13.9 \%$ & $4.3 \%$ & $4.3 \%$ & $7.6 \%$ & $6.8 \%$ & $12.1 \%$ & $7.1 \%$ \\
\hline Other Taxes & $10.5 \%$ &.-- & $10.0 \%$ & $0.0 \%$ & $7.1 \%$ & $7.1 \%$ & $2.3 \%$ & $2.3 \%$ & $3.4 \%$ & $0.4 \%$ & $10.2 \%$ & $3.2 \%$ \\
\hline $\begin{array}{l}\text { of which Social Security Contributions } \\
\text { with Pensions (in sensitivity analysis) }\end{array}$ & $6.7 \%$ &.-- & $0.0 \%$ & $0.0 \%$ & $7.1 \%$ & $7.1 \%$ & $2.3 \%$ & $2.3 \%$ & $1.9 \%$ & $0.4 \%$ & $5.6 \%$ & $3.2 \%$ \\
\hline $\begin{array}{l}\text { Memo: Social Security Contributions witbout } \\
\text { Pensions (benchmark scenario) }\end{array}$ & na & $\because-$ & $0.0 \%$ & $0.0 \%$ & $0.0 \%$ & $0.0 \%$ & $1.6 \%$ & $1.6 \%$ & $1.4 \%$ & $0.0 \%$ & $0.0 \%$ & $0.0 \%$ \\
\hline Non-Tax Revenues & $9.6 \%$ & -.- & $4.7 \%$ & $0.0 \%$ & $9.6 \%$ & $0.0 \%$ & $10.8 \%$ & $0.0 \%$ & $8.0 \%$ & $0.0 \%$ & $1.7 \%$ & $0.0 \%$ \\
\hline
\end{tabular}

Argentina: Lustig and Pessino (forthcoming); Bolivia: Paz Arauco et al. (forthcoming); Brazil: Higgins and Pereira (forthcoming); Mexico: Scott (forthcoming); Peru: Jaramillo (forthcoming); and Uruguay: Bucheli et al. (forthcoming).

GNI per capita from the World Development Indicators: http://data.worldbank.org/indicator/NY.GNP.PCAP.KD

Argentina: Dirección Nacional de Gasto Público and Dirección Nacional de Presupuesto, Ministry of Economy Argentina, ANSES.

Bolivia: Ministerio de Economía y Finanzas Públicas (2011), Autoridad de Pensiones y Seguros (2011), UDAPE. http://www.udape.gob.bo/. Data for Desayuno Escolar and PAN are based on own calculations.

Brazil: Ministerio da Fazenda (2010), SAGI and MDS (2012), MDS (2011), Secretaria do Desenvolvimento Social, Governo do Estado de São Paulo, Ministério do Trabalho (2011), Portal da Transparência, Controladora Geral da União, Ministério da Agricultura, Pecuaria e Abastecimento (2009), Ministério de Previdência e Assistência Social (2009), Amaral et al. (2011).

Mexico: ENIGH 2010 and Cuenta Pública 2010. 
Peru: Sistema Integrado de Información Financiera (SIAF) and Unidad de Estadística Educativa (ESCALE). Taxes from Superintendencia Nacional de Aduanas y Administración Tributaria (SUNAT). Government Spending from Banco Central de Reserva del Peru (BCRP).

Uruguay: BPS, MEF, JUNASA, MIDES, and OPP.

Notes:

"-.-": not applicable because the study for Argentina does not include the incidence of taxes

"na": not available

a. In Incidence Analysis

b. Total Government Spending = Primary Government Spending + Debt Services (interests and amortizations)

c. Primary Government Spending = Social Spending (w/o Contributory Pensions) + Non-social Spending (w/o Contributory Pensions) + Contributory Pensions

d. Social Spending = Total Cash Transfers + Total In-kind Transfers + Other Social Spending

e. For Brazil the figure for noncontributory pensions includes only the flagship noncontributory pension program, Benefício de Prestação Continuada, and no other noncontributory pensions programs, such as the Special Circumstances Pensions.

f. Education spending in Bolivia and education and health spending in Peru in incidence analysis are net of administrative costs (but the totals from public accounts do include them) so shares are not comparable with the other countries; in Bolivia and Peru administrative costs were added to "Other Social Spending." The incidence analysis for Argentina includes only public spending on noncontributory health. In Brazil all public health is noncontributory. The incidence analyses for Bolivia, Mexico, Peru, and Uruguay include both contributory and noncontributory health. Except for Uruguay, spending on education and health includes both recurrent and capital expenditures; Uruguay includes recurrent expenditures only.

g. Argentina does not include incidence analysis for public spending on contributory health systems or taxes.

h. Non-social Spending = Indirect Subsidies + Other Non-social Spending. Note that the value under total for Mexico here differs from Scott's forthcoming paper in the Public Finance Review because the value here excludes contributory pensions.

i. Other Non-social Spending = Government Administration + any additional non-social spending not already included. Note that the value under total for Mexico here differs from Scott's forthcoming paper in the Public Finance Review because the value here excludes contributory pensions.

j. "Contributory pensions" reported for Mexico correspond to federal government spending on contributory pensions. This value differs from total pension income reported in the household survey (4.0\% of GDP, adjusted to National Accounts). In the sensitivity analysis of the forthcoming paper for the Public Finance Review, Scott used $4.0 \%$.

k. Argentina does not include an analysis of taxes. In Bolivia, taxes in the benchmark include: Value Added Tax (VAT), Specific Consumption Tax (ICE), Hydrocarbons Tax (IEHD), and Transactions Tax (IT). Other Taxes (not in Incidence Analysis) include other taxes from which $6.7 \%$ of GDP corresponds to direct hydrocarbons tax (IDH), and 3\% to hydrocarbons royalties and other taxes applied to enterprises and private entities. IDH is a direct tax applied to hydrocarbons production to be distributed to regions. IEHD is a transaction tax applied to individuals and enterprises. Unlike the other countries, the indirect taxes in Brazil are atypical, since they consist of different taxes leveled at different government levels, and that also vary by type of goods and services considered. Indirect taxes in Brazil include a state tax called ICMS, a federal tax, an industrialized products tax, and a cascading tax that is in the process of changing to a more typical VAT tax, the PIS/COFINS. Mexico includes VAT and other indirect taxes. Peru includes VAT and excise taxes on fuels. Uruguay includes VAT and other indirect taxes.

1. In Argentina, the values are not available. In Peru, the incidence analysis for the benchmark scenario did not subtract the contributions to social security that were not for pensions (such as contributions for the contributory health system). In the other country studies that include the tax side in the analysis, the benchmark scenario does account for the social security contributions other than the contributions for pensions. In Uruguay, it is not possible to distinguish the portion that goes to pensions so in the benchmark scenario, no contributions were deducted to get net market income.

m. The incidence analysis for Peru differs slightly from the incidence analysis column from Table 1 from Jaramillo in the forthcoming paper for the Public Finance Review because here the data on education and health spending does not include administrative costs while in Jaramillo, it does. The incidence analysis for education and health spending in Jaramillo was carried out excluding administrative costs.

n. Peru has a subsidy to gasoline and other oil derivatives; however, the actual numbers spent on this subsidy were not publicly available at the time of the analysis.

\section{iii Direct (mainly Personal Income) Taxes}

There is quite a bit of variation in terms of how much individual personal incomes are taxed. Total revenues generated from this source range from 4.7 percent in Uruguay to 0.2 percent in Bolivia (revenues from personal income taxes included in incidence analysis range from 4.7 percent of GDP in Uruguay to zero percent in Bolivia and Argentina) (Table 2) ${ }^{16}$ As expected, personal income taxes are progressive in Brazil,

${ }^{16}$ In Bolivia, there is a direct tax called RC-VAT but it represents less than 1 percent of total tax revenues and the burden cannot 
Mexico, Peru, and Uruguay. However, their redistributive power varies: Uruguay's, Mexico's, and Brazil's Ginis decline by 2.8, 2.6, and 2.4 percent, respectively, while Peru's declines by only 1.1 percent (Table 1 and Figure 1). For the relatively small amount of direct taxes collected by Peru, their redistributive effect is relatively large (Table 1).

\section{iv Direct (mainly Cash) Transfers}

There is also quite a bit of variation in terms of how much governments spend on direct cash transfers ranging from as much as 4.2 percent in Brazil to as little as 0.4 percent in Peru (Table 2). Cash transfers are of two main kinds: conditional cash transfers (CCTs) and noncontributory pensions. In some countries, food transfers and unemployment benefits are important as well.

Conditional cash transfers (CCTs) are designed to reduce income poverty and, at the same time, keep children in school and subject them to regular health check-ups (although not all of them include the health component). Spending on CCTs ranges from 0.15 percent of GDP in Peru to 0.63 percent of GDP in Argentina (Jaramillo, forthcoming; Lustig and Pessino, forthcoming). The effect of CCTs, which are the most progressive of all programs in some countries, is progressive in absolute terms in every country and highly so in all but Bolivia where it is moderately progressive in absolute terms (Table 3). In particular, the concentration coefficients for the countries' flagship CCTs are as follows: Peru's Juntos -.65, Uruguay's Asignaciones Familiares -.61, Brazil's Bolsa Família -.58, Mexico's Oportunidades -.54, Argentina's Asignación Universal por Hijo -.50, and Bolivia's Juancito Pinto -0.25. Bolivia has the lowest (in absolute value) concentration coefficient because it does not rely on means or proxy means testing to identify beneficiaries: all children attending primary and secondary public schools are eligible.

be allocated to individuals in any straightforward way so it was not included in the incidence analysis. 
TABLE 3. PROGRESSIVITY AND REGRESSIVITY OF TAXES AND TRANSFERS

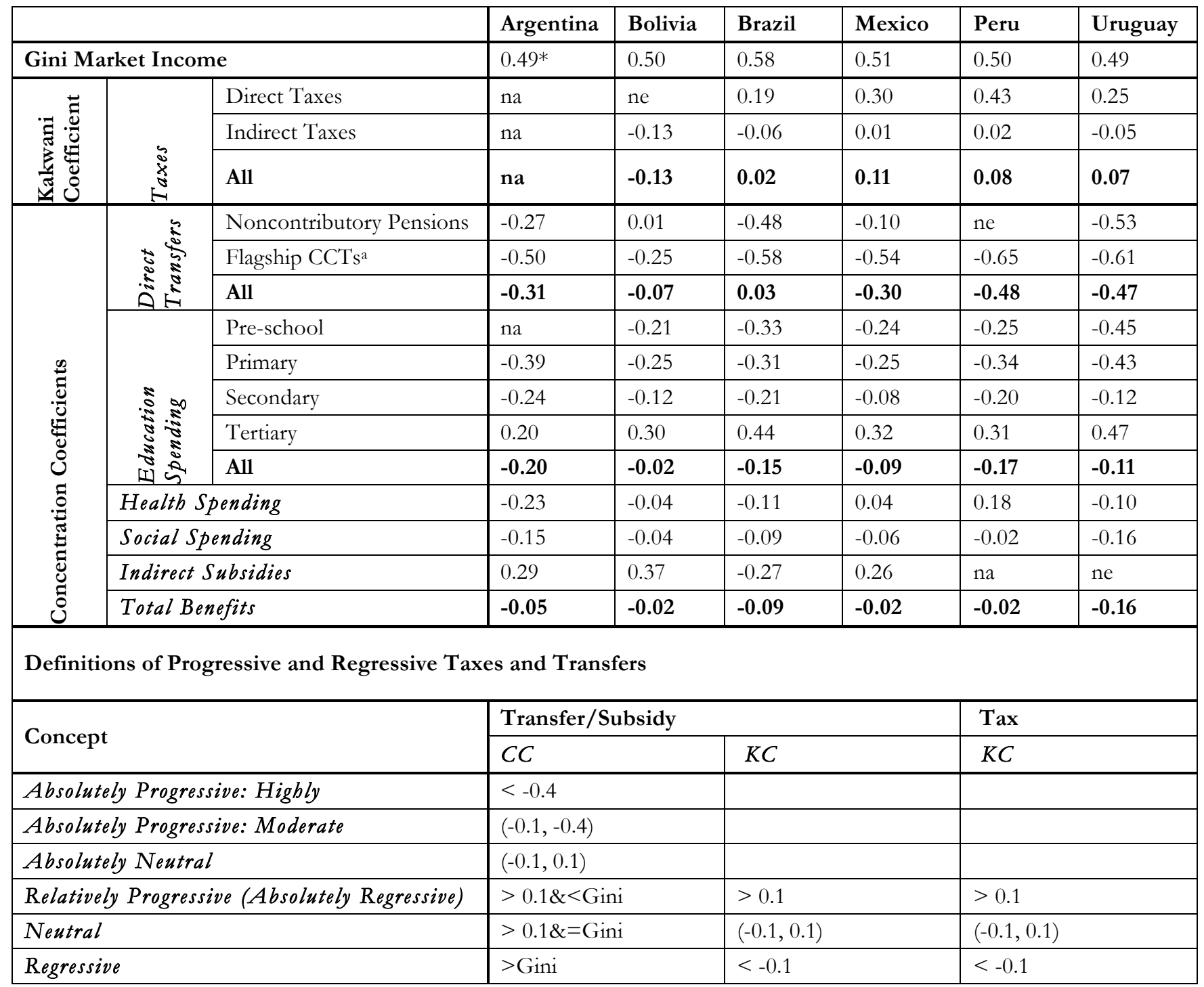

Argentina: Lustig and Pessino (forthcoming); Bolivia: Paz Arauco et al. (forthcoming); Brazil: Higgins and Pereira (forthcoming); Mexico: Scott (forthcoming); Peru: Jaramillo (forthcoming); and Uruguay: Bucheli et al. (forthcoming).

Notes:

"na": not available because not included in incidence analysis

"ne": nonexistent

*: Gini for Net Market Income

a. The countries' flagship CCTs are as follows: Peru's Juntos, Uruguay's Asignaciones Familiares, Brazil's Bolsa Família, Mexico's Oportunidades, Argentina's Asignación Universal por Hijo, and Bolivia’s Juancito Pinto. 
Noncontributory (old-age) pensions are the second most common cash transfer. Only Peru (at the time of the survey) did not have such a program but has launched a program since. ${ }^{17}$ Essentially, these programs transfer cash to individuals 65 years old or older who have never contributed to the formal social security system or have not contributed enough to be eligible for a minimum old-age pension. In the case of Argentina and to a lesser extent in Bolivia, spending on noncontributory pensions is quite high: 2.9 and 1.4 percent of GDP (Table 2), which is, respectively, more than three times and double what is spent on other cash transfers (mainly CCTs). In Uruguay and Mexico, on the other hand, spending on noncontributory pensions is only 0.5 and 0.2 percent of GDP, respectively. However, lax enforcement of eligibility in the past leads one to believe that spending on contributory pensions in Uruguay-among the highest of allincludes payments to individuals who did not contribute or did not contribute enough to become eligible. ${ }^{18}$

Noncontributory pensions are quite progressive in absolute terms in Uruguay and Brazil where the concentration coefficients equal -.53 and -.48, respectively (Table 3). In Argentina and Mexico they are progressive in absolute terms but to a lesser extent: concentration coefficients equal -.27 and $-.10,{ }^{19}$ respectively. However, the lower absolute progressivity in the case of Argentina, for example, is not because a large proportion of social spending accrues to the middle-class and the rich. In Argentina in 2009, 35 percent of the benefits of noncontributory pensions accrue to individuals with market incomes of less than US\$2.50 PPP per day (conventionally considered the extreme poverty line for Latin America) and 43 percent accrues to individuals with market incomes of less than US\$4 PPP per day (conventionally considered the moderate poverty line for Latin America). Of the remaining 57 percent, about two thirds accrues to individuals with market incomes equal to or above US\$4 PPP and below US\$10 PPP per day (Table 4). This group has been defined as "vulnerable" to falling into poverty (López-Calva and Ortiz-Juarez, 2013). With a concentration coefficient of .015, Bolivia is the only country where noncontributory pensions are not progressive but neutral in absolute terms: that is, the per capita transfer is approximately the same regardless of income. The results for both Bolivia and Mexico reflect the universal, non-targeted design of their noncontributory pension programs.

As shown in Table 1 and Figures 1 and 2, Uruguay and Argentina are the countries that achieve the most inequality and poverty reduction through direct transfers, followed by Brazil. On the other extreme are Bolivia and Peru, each for very different reasons. As one can observe in Table 1, Peru is very effective in terms of how much inequality and poverty reduction is achieved per percent of GDP spent on direct transfers. The scale of redistribution and poverty reduction is small because Peru spends so little on cash

\footnotetext{
17 The program is called "Pension 65" and it was launched in 2011. It is means-tested and it has more than 200,000 beneficiaries. Individuals who are 65 or older and live in extreme poverty are eligible as long as they don't receive pensions from other sources or other government benefits except for "Juntos" (a CCT) and "SIS" (the noncontributory health program).

${ }^{18}$ In the case of Uruguay, because the government did not have a registry of employment history up until 1996, an unknown number of individuals who received contributory old-age pensions in the year of the survey were probably ineligible (that is, they had probably not fulfilled the required 30 years of contributions). Thus, the 8.7 percent of GDP that the government spends on social security benefits includes an unknown amount that in reality should have been classified as noncontributory pensions. If the individuals who received the pensions by dodging the system disproportionately belonged to the poor, the redistributive and poverty-reducing impact of Uruguay's social spending would have been even higher than what was found.

${ }^{19}$ This includes the federal noncontributory pension (70 y más), which is universal in rural and semi-urban areas (in 2013 it has been made universal in all areas and extended to 65+ year olds). In addition many states have local noncontributory pension programs, which range widely in progressivity (measured at the national level), reflecting in part the income disparities between states. The national average for all noncontributory programs is -0.10 .
} 
transfers. In contrast, Bolivia spends (as a share of GDP) five times more on cash transfers than Peru but because funds are weakly targeted (in the case of Juancito Pinto) or not targeted at all to the poor (in the case of noncontributory pensions), the scale of redistribution and poverty reduction is quite limited. In this spectrum of redistributive effects, Mexico is more similar to Peru, but because Mexico spends more on direct transfers than Peru, the redistributive results are larger in Mexico.

In spite of spending a relatively large amount on cash transfers, Brazil's effectiveness in reducing inequality and poverty is relatively low (Tables 1 and 2). This is due to unemployment benefits, scholarships, and, especially, the so-called Special Circumstances Pensions, a noncontributory-but part of the formal social security system—social insurance scheme for people who suffer accidents at work or become widows. ${ }^{20}$ For example, the government spent 2.3 percent of GDP on Special Circumstances Pensions in 2009 and its concentration coefficient is .20 (Higgins and Pereira, forthcoming). Only 16 percent of the benefits accrue to individuals with incomes less than US\$4 PPP a day (26 percent of the population); in contrast, 43 percent of the program's total benefits accrue to individuals between US\$10 to US\$50 PPP (36 percent of the population) and 14 percent to individuals with daily incomes above US\$50 PPP (5 percent of the population) (Table 4). ${ }^{21}$

All six countries considered here have CCTs and five have noncontributory pensions. Nevertheless, with the exception of Argentina and Uruguay, after direct transfers (and taxes) extreme poverty rates (individuals under the US\$2.50 PPP/day international poverty line) are still above 10 percent. This reflects in part higher market income poverty rates in these countries (with the exception of Mexico where pre-transfer poverty is actually slightly lower than in Argentina), but is also due to gaps in the coverage of the extreme poor, the size of benefits, or both. In Brazil and Bolivia the coverage is near universal. Cash transfers reach 93 percent of the extreme poor in Brazil and 88 percent of the extreme poor in Bolivia (Table 4). Thus, the persistence of extreme poverty is due to the size of the benefit in comparison with the poverty gap as well as to their distribution among the poor. In Bolivia, the average daily transfer (of all programs combined) to the extreme poor (those below the US\$2.50 PPP/day poverty line) equals US\$.27 PPP while the average poverty gap is US\$1.25 PPP. In Brazil, these numbers are US\$.83 PPP and US\$1.05 PPP, respectively. Furthermore, these average benefits hide inequality in benefits among the poor. In Peru, coverage is a mere 58 percent, while in Mexico, coverage is 73 percent so there is room for improvement in coverage too (Table 4). Hence, increasing coverage, the size of benefit, and their equity among the poor may be needed to eradicate extreme forms of poverty depending on the country.

\footnotetext{
${ }^{20}$ Most of the benefits under "Special Circumstances Pensions" require being registered in the formal social security system. Eligibility only requires being currently registered and not a history of contributions. However, by definition these transfers are likely to have an anti-poor bias since most of the poor work in the informal sector and are not registered in the social security system. If this transfer were included with market income as contributory old-age pensions are, the impact of government taxes and transfers on inequality and poverty change, but only slightly.

${ }^{21}$ These two income categories have been called "middle-class" and "rich" in a recent report by World Bank (Ferreira et al., 2013).
} 
TABLE 4. DISTRIBUTION AND COVERAGE OF SOCIAL SPENDING BENEFITS

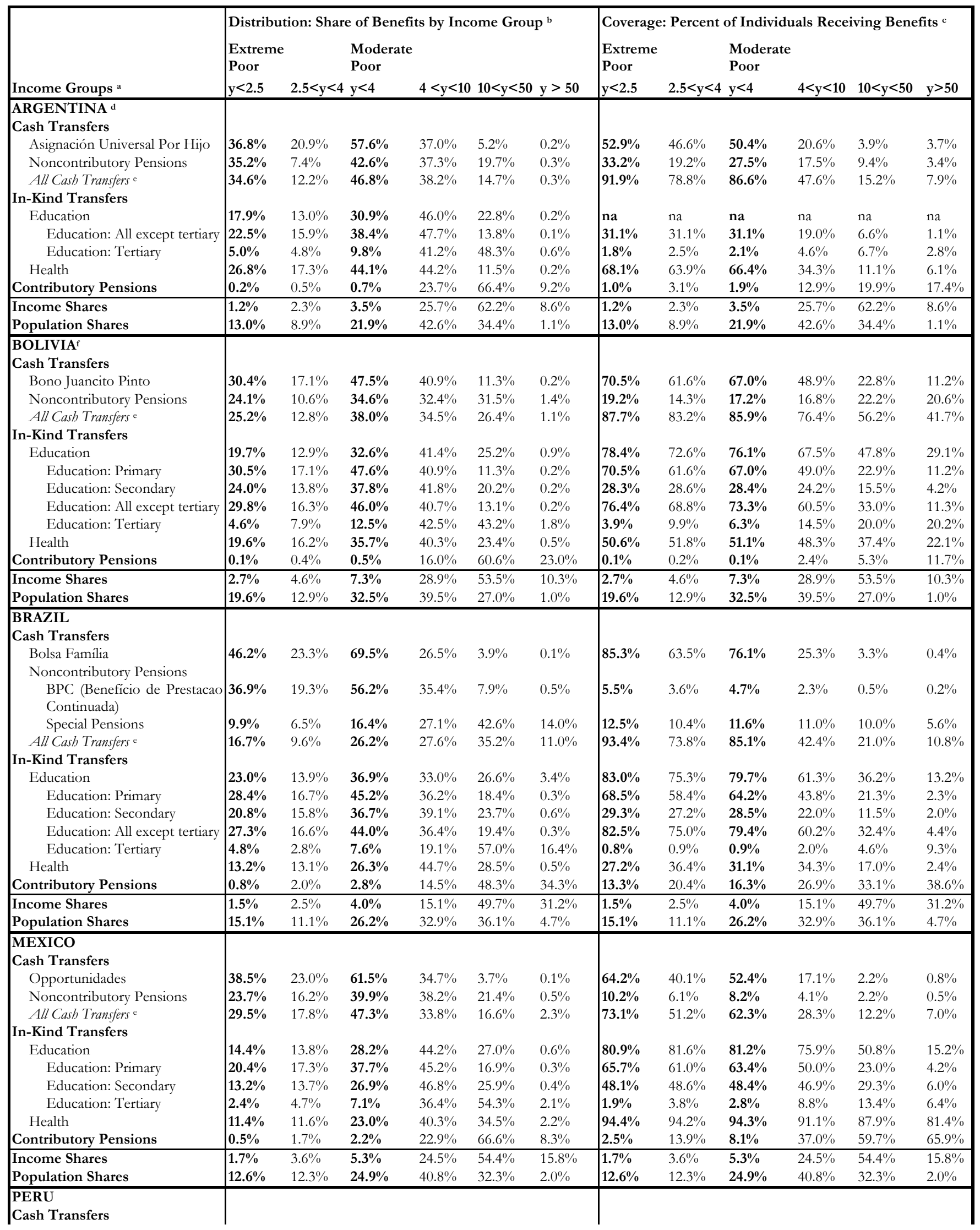




\begin{tabular}{|c|c|c|c|c|c|c|c|c|c|c|c|c|}
\hline Juntos & $55.7 \%$ & $25.5 \%$ & $81.3 \%$ & $17.1 \%$ & $1.7 \%$ & $0.0 \%$ & $35.3 \%$ & $17.4 \%$ & $26.9 \%$ & $3.7 \%$ & $0.4 \%$ & $0.0 \%$ \\
\hline Noncontributory Pensions g &.-- &.-- &.-- &.-- &.-- &.-- & -.- &.-- &.-- &.-- &.-- &.-- \\
\hline All Cash Transfers $\mathrm{e}$ & $46.9 \%$ & $24.0 \%$ & $70.9 \%$ & $24.0 \%$ & $5.1 \%$ & $0.0 \%$ & $57.7 \%$ & $41.9 \%$ & $50.3 \%$ & $23.0 \%$ & $7.6 \%$ & $0.2 \%$ \\
\hline \multicolumn{13}{|l|}{ In-Kind Transfers } \\
\hline Education & $22.2 \%$ & $18.5 \%$ & $40.7 \%$ & $40.5 \%$ & $18.5 \%$ & $0.3 \%$ & $58.2 \%$ & $53.2 \%$ & $55.8 \%$ & $40.1 \%$ & $18.5 \%$ & $3.8 \%$ \\
\hline Education: Primary & $29.3 \%$ & $21.5 \%$ & $50.7 \%$ & $37.4 \%$ & $11.8 \%$ & $0.1 \%$ & $16.5 \%$ & $13.7 \%$ & $15.2 \%$ & $8.5 \%$ & $3.1 \%$ & $0.3 \%$ \\
\hline Education: Secondary & $19.2 \%$ & $18.5 \%$ & $37.7 \%$ & $44.6 \%$ & $17.6 \%$ & $0.2 \%$ & $8.7 \%$ & $9.4 \%$ & $9.0 \%$ & $8.1 \%$ & $3.8 \%$ & $0.6 \%$ \\
\hline Education: All except tertiary & $24.6 \%$ & $19.8 \%$ & $44.4 \%$ & $40.9 \%$ & $14.7 \%$ & $0.1 \%$ & $28.9 \%$ & $26.1 \%$ & $27.6 \%$ & $19.2 \%$ & $8.1 \%$ & $1.1 \%$ \\
\hline $\begin{array}{l}\text { Education: Tertiary } \\
\text { Health }\end{array}$ & $3.6 \%$ & $8.1 \%$ & $11.6 \%$ & $37.2 \%$ & $49.1 \%$ & $2.1 \%$ & $0.4 \%$ & $1.0 \%$ & $0.7 \%$ & $1.6 \%$ & $2.3 \%$ & $1.6 \%$ \\
\hline & $8.8 \%$ & $8.9 \%$ & $17.8 \%$ & $35.4 \%$ & $44.0 \%$ & $2.8 \%$ & $92.5 \%$ & $89.3 \%$ & $91.0 \%$ & $83.8 \%$ & $82.9 \%$ & $72.5 \%$ \\
\hline Contributory Pensions & $0.1 \%$ & $0.6 \%$ & $0.7 \%$ & $13.5 \%$ & $71.2 \%$ & $14.5 \%$ & $0.5 \%$ & $1.4 \%$ & $0.9 \%$ & $4.9 \%$ & $13.8 \%$ & $19.0 \%$ \\
\hline Income shares & $2.3 \%$ & $4.1 \%$ & $6.3 \%$ & $23.4 \%$ & $54.8 \%$ & $15.5 \%$ & $2.3 \%$ & $4.1 \%$ & $6.3 \%$ & $23.4 \%$ & $54.8 \%$ & $15.5 \%$ \\
\hline Population shares & $15.1 \%$ & $13.4 \%$ & $28.6 \%$ & $37.5 \%$ & $32.0 \%$ & $2.0 \%$ & $15.1 \%$ & $13.4 \%$ & $28.6 \%$ & $37.5 \%$ & $32.0 \%$ & $2.0 \%$ \\
\hline \multicolumn{13}{|l|}{ URUGUAY } \\
\hline \multicolumn{13}{|l|}{ Cash Transfers } \\
\hline Asignaciones Familiares & $20.8 \%$ & $22.3 \%$ & $43.1 \%$ & $44.1 \%$ & $12.7 \%$ & $0.1 \%$ & $80.0 \%$ & $69.0 \%$ & $73.9 \%$ & $32.5 \%$ & $5.0 \%$ & $0.3 \%$ \\
\hline Noncontributory Pensions & $20.1 \%$ & $15.6 \%$ & $35.6 \%$ & $42.0 \%$ & $21.9 \%$ & $0.4 \%$ & $19.7 \%$ & $12.6 \%$ & $15.7 \%$ & $7.3 \%$ & $2.0 \%$ & $0.3 \%$ \\
\hline All Cash Transfers ${ }^{\mathrm{e}}$ & $17.8 \%$ & $16.0 \%$ & $33.8 \%$ & $40.5 \%$ & $24.9 \%$ & $0.8 \%$ & $97.1 \%$ & $92.8 \%$ & $94.7 \%$ & $69.1 \%$ & $22.5 \%$ & $2.2 \%$ \\
\hline \multicolumn{13}{|l|}{ In-Kind Transfers } \\
\hline Education & $7.7 \%$ & $8.8 \%$ & $16.5 \%$ & $31.6 \%$ & $47.9 \%$ & $4.0 \%$ & na & na & na & na & na & na \\
\hline Education: Primary & $14.6 \%$ & $15.1 \%$ & $29.7 \%$ & $42.4 \%$ & $27.6 \%$ & $0.3 \%$ & $82.7 \%$ & $76.1 \%$ & $79.0 \%$ & $55.2 \%$ & $20.2 \%$ & $2.2 \%$ \\
\hline $\begin{array}{l}\text { Education: Secondary (ciclo } \\
\text { básico) }\end{array}$ & $6.6 \%$ & $9.6 \%$ & $16.2 \%$ & $42.7 \%$ & $40.3 \%$ & $0.8 \%$ & $23.1 \%$ & $25.6 \%$ & $24.5 \%$ & $23.3 \%$ & $10.4 \%$ & $1.6 \%$ \\
\hline $\begin{array}{l}\text { Education: } \\
\text { (bachillerato) }\end{array}$ & $1.7 \%$ & $3.4 \%$ & $5.1 \%$ & $24.0 \%$ & $67.6 \%$ & $3.3 \%$ & $4.2 \%$ & $5.6 \%$ & $5.0 \%$ & $8.3 \%$ & $10.1 \%$ & $3.9 \%$ \\
\hline $\begin{array}{l}\text { Education: } \quad \text { Secondary } \\
\text { technical }\end{array}$ & $3.4 \%$ & $4.6 \%$ & $8.1 \%$ & $30.3 \%$ & $59.4 \%$ & $2.2 \%$ & $4.5 \%$ & $4.5 \%$ & $4.5 \%$ & $6.3 \%$ & $5.0 \%$ & $1.0 \%$ \\
\hline Education: All except tertiary & $9.8 \%$ & $11.1 \%$ & $21.0 \%$ & $38.5 \%$ & $39.5 \%$ & $1.1 \%$ & $87.5 \%$ & $84.5 \%$ & $85.8 \%$ & $70.6 \%$ & $37.9 \%$ & $8.0 \%$ \\
\hline Education: Tertiary & $0.0 \%$ & $0.6 \%$ & $0.6 \%$ & $7.1 \%$ & $77.9 \%$ & $14.5 \%$ & $0.0 \%$ & $1.0 \%$ & $0.5 \%$ & $2.4 \%$ & $10.0 \%$ & $13.9 \%$ \\
\hline Health & $6.4 \%$ & $8.0 \%$ & $14.3 \%$ & $32.2 \%$ & $49.0 \%$ & $4.5 \%$ & $98.7 \%$ & $98.7 \%$ & $98.7 \%$ & $98.0 \%$ & $89.6 \%$ & $76.8 \%$ \\
\hline Contributory Pensions & $10.8 \%$ & $9.6 \%$ & $20.4 \%$ & $33.3 \%$ & $41.6 \%$ & $4.6 \%$ & $73.6 \%$ & $54.8 \%$ & $63.1 \%$ & $40.5 \%$ & $22.0 \%$ & $13.1 \%$ \\
\hline Income Shares & $0.4 \%$ & $1.1 \%$ & $1.5 \%$ & $10.0 \%$ & $59.3 \%$ & $29.2 \%$ & $0.4 \%$ & $1.1 \%$ & $1.5 \%$ & $10.0 \%$ & $59.3 \%$ & $29.2 \%$ \\
\hline Population Shares & $5.1 \%$ & $6.5 \%$ & $11.6 \%$ & $27.8 \%$ & $53.8 \%$ & $6.8 \%$ & $5.1 \%$ & $6.5 \%$ & $11.6 \%$ & $27.8 \%$ & $53.8 \%$ & $6.8 \%$ \\
\hline
\end{tabular}

Sources: Argentina: Lustig and Pessino (forthcoming); Bolivia: Paz Arauco et al. (forthcoming); Brazil: Higgins and Pereira (forthcoming); Mexico: Scott (forthcoming); Peru: Jaramillo (forthcoming); and Uruguay: Bucheli et al. (forthcoming).

Notes:

"-.-": not applicable

"na": not available

a. Income groups are based on net market income measured in US\$ PPP per day for Argentina, Bolivia, and Mexico and on market income measured in US \$PPP per day for Brazil, Peru, and Uruguay. Neither income nor benefits are scaled to National Accounts. The bolded columns " $y<2.5$ " and " $y<4$ " correspond to those in extreme poverty and moderate poverty, respectively.

b. Distribution is measured as the share of social spending benefits received by each income group.

c. Coverage is measured with respect to the population of the income groups. The "Percent of Individuals Receiving Benefits" is the percent of individual in each income group living in beneficiary households.

d. The study for Argentina (Lustig and Pessino, forthcoming) does not analyze the tax side of the fiscal system. As such, income groups and income shares are found using net market income. The results are thus not strictly comparable.

e. The category All Cash Transfers includes all cash transfer benefits, at least one per beneficiary.

f. Since in Bolivia personal income taxes are practically nil, the indicators for market income in Bolivia are identical as the indicators for net market income; for details see Paz Arauco et al. (forthcoming).

g. At the time of the analysis, Peru did not have a noncontributory pension system.

\section{$\checkmark$ Indirect (Consumption) Taxes}

Total revenues from indirect taxes as a share of GDP range from as low as 4.3 percent in Mexico, to as high as 15.2 percent in Brazil (revenues included in the incidence analysis range from 4.3 percent in Mexico to 13.9 percent in Brazil) (Table 2). Indirect taxes are regressive in Bolivia, neutral in Mexico and Peru, and close to neutral in Brazil and Uruguay (Table 3). In Peru, this is partly by design (e.g., food exemptions) but is also due to the distribution of consumption tax evasion. In Peru it was assumed that individuals in remote rural areas (villages with less than 100 households) and those who purchase in so-called informal 
establishments in urban areas do not pay VAT or other indirect taxes. Since the poor are more concentrated in rural areas and poor people in rural and urban areas tend to buy more from informal (nontax-paying) outlets than the nonpoor, tax evasion is pro-poor in this instance. In effect, if the government were to crack down on informality, indirect taxes in Peru would become more regressive. In the case of Mexico the lack of regressivity reflects informality as well as design: there are broad VAT exemptions on food and medicines, which also account for Mexico's low indirect tax revenue.

To what extent do indirect taxes offset what is accomplished through direct taxes and transfers in terms of inequality and poverty reduction? Because the post-fiscal income category includes the impact of indirect subsidies in the cases of Bolivia, Brazil, and Mexico but not in Peru (Uruguay does not have indirect consumption subsidies), the comparison is not perfect. In Bolivia, Brazil, and Uruguay, the post-fiscal income inequality is slightly higher than the disposable income inequality but only in Bolivia is the effect large enough to offset the equalizing impact of direct transfers. In the cases of Mexico and Peru, the postfiscal income inequality is slightly below the disposable income inequality (Figure 1).

The impact of indirect taxes on poverty, however, is more pernicious. We shall use three indicators to illustrate this: the incidence of poverty with the international extreme poverty line of US $\$ 2.50$ PPP per day; at what income decile and socio-economic group individuals become net payers to the fiscal system on average (before transfers in-kind, that is); and the proportion of individuals moving from near-poor to moderate poverty or from moderate poverty to extreme poverty induced by the effect of indirect taxes (Lustig and Higgins, 2012).

In Bolivia and Brazil, the incidence of extreme poverty (less than US\$2.50 PPP/day) with post-fiscal income is higher than the incidence of extreme poverty with net market income (Figure 2). In the case of Brazil, the "offsetting" of cash transfer benefits is dramatic: direct transfers reduce net market income extreme poverty from 15.7 percent to a disposable income extreme poverty rate of 11.2 percent, but indirect taxes bring it back up to a post-fiscal income extreme poverty of 16.3 percent. The reversal is also important but less markedly in Uruguay; in particular, post-fiscal income extreme poverty equals 2.3 percent, which is still half as much as net market income extreme poverty at 5.1 percent, but higher than disposable income extreme poverty which equals 1.5 percent. In Brazil and Uruguay, however, the poverty-increasing impact of indirect taxes may be overestimated due to the assumptions of no evasion of indirect (consumption) taxes (Uruguay) and no differences in evasion rates along the income distribution (Brazil). In Mexico, one important reason why post-fiscal income poverty is (slightly) lower than disposable income poverty is the effect of indirect subsidies and broad VAT exemptions on food and medicines.

In Peru the lowest decile in which people are net payers is the second decile; in Bolivia and Uruguay it is the third decile while in Brazil it is the fourth and in Mexico it is the fifth. While only in Brazil and Peru, on average, the net payer to the fiscal system is among the poor, in Mexico, the net payer, on average, belongs to the "vulnerable" group (with per capita market income equal or higher than US\$4 and lower than US\$10 PPP per day). Moreover, in Bolivia, more than 15 percent of the moderate poor are pushed down into extreme poverty and more than 8 percent of the extreme poor are pushed into ultra-poverty as a result of indirect taxes (Ultra-poverty is defined by the US\$1.25 PPP per day international poverty line.) In Brazil, 27 percent of the moderate poor are pushed down into extreme poverty and 4.5 percent of the extreme poor are pushed into ultra-poverty. 
Total spending on education ranges from 8.3 percent of GDP in Bolivia ${ }^{22}$ to 2.8 percent of GDP in Peru. Total health spending ranges from 6.2 percent of GDP in Argentina to 3.1 percent in both Peru and Mexico. The incidence analysis includes education spending that ranges from 8.3 percent of GDP in Bolivia to 2.1 percent in Peru and health spending that ranges from 5.2 percent in Brazil to 2.3 percent in Peru (Table 2). In four countries spending on education is moderately progressive in absolute terms, and in the remaining two, it is neutral in absolute terms (Bolivia) or close to neutral in absolute terms (Mexico). The redistributive impact of public spending on health varies more widely: it is moderately progressive in absolute terms in Argentina (but this excludes spending on contributory health so it is not strictly comparable) and Brazil, slightly progressive in absolute terms in Uruguay, close to neutral in absolute terms in Bolivia and Mexico, and progressive only in relative terms in Peru.

In all six countries the bulk of redistribution is achieved through public education and public health (Table 1). If one takes into account the monetized-equivalent (at government cost) of these transfers in-kind, the final income Gini associated with social spending as a whole (when compared with market income) declines by 14.0 percentage points in Brazil, 12.3 percentage points in Argentina (though not strictly comparable for reasons explained above), 9.9 percentage points in Uruguay, 8.1 percentage points in Mexico, 5.7 percentage points in Bolivia, and only 3.8 percentage points in Peru (Figure 1).

Why is Peru the least redistributive? For two main reasons: the amount of social spending is relatively small (Table 2) and the total redistributive effectiveness of social spending is the second lowest (after Bolivia; Table 1). This occurs despite Peru's effectiveness in the use of cash transfers where it ranks at the top. The main reason that explains why Peru fares worse when transfers in-kind are added is because health spending-although still progressive in relative terms-is the least progressive among the six countries studied here (readers should remember, however, that Argentina's analysis does not include contributory health spending). Education spending in Peru, on the other hand, is progressive in absolute terms. Even university education with a concentration coefficient of 0.31 is not "pro-rich:" the group with market income above US $\$ 50$ per day captures a share equal to its population share (around 2 percent) (Table 4). As we shall see below, this is in stark contrast with Brazil and Uruguay.

Redistribution in Bolivia through in-kind transfers is limited for reasons that are quite different than for Peru. In Bolivia, the share of spending on education and health as a share of GDP is rather large, especially for education. The limited redistributive power stems from the fact that per capita spending is practically the same for everyone, as indicated by concentration coefficients (almost) equal to zero (-.02 for education and .04 for health, Table 3). Since coverage of basic education among the extreme poor is not universal and poorer families have more school-age children, equal per capita transfers in the education benefits is not a positive result from the equity standpoint. In a country like Bolivia with a high incidence of poverty, we would like to observe more "pro-poor" (higher progressivity in absolute terms) education and health spending. It is important to note that the lack of greater progressivity in education spending is not due to

\footnotetext{
${ }^{22}$ Since official accounts on social spending are not available for 2009, data on in-kind education transfers are based on our own estimations. We assume a similar structure of education expenditures as the one registered in 2007, and a sector growth rate over the period 2008-2009 similar to the one registered between 2007 and 2008. Data comes from UDAPE. http://www.udape.gob.bo/.
} 
the distribution of benefits of tertiary education but rather is due to the exceptionally high share of spending on tertiary education in the total education budget. With a concentration coefficient of .30, spending on tertiary education is not particularly "pro-rich." The lion's share of tertiary public education in Bolivia accrues to the "middle class" (between US\$10 and US\$50 PPP per day) (Table 4). Thus, the issue is more the fact that access to basic education among children in poor households is not universal. The low progressivity of education spending is explained by (1) the comparatively low progressivity of primary education (due to low coverage rates among the poor) and (2) an exceptionally high allocation of educational spending to tertiary education.

\section{vii Contributory Pensions as Government Transfers}

As noted at the beginning of this overview, contributory pensions have been treated in these studies as part of market income. However, contributory pension systems can have important redistributive effects for two reasons. First, very few contributory systems are purely contributory: most systems include public (taxfinanced) subsidies, including universal government contributions, minimum pension guarantees for workers who have not achieved the required contribution density, or transitional financing of old pay-asyou-go pensions in the context of reforms towards fully financed systems. Secondly, even in the absence of such subsidies, all contributory pension systems inevitably entail redistributions among the pool of contributor-beneficiaries. For these reasons, the Commitment to Equity studies included a sensitivity analysis treating contributory pensions as direct transfers.

Considered as transfers, contributory pensions would represent massive expansions in social spending. With respect to the benchmark incidence analysis, the expansions range from 81.4, 61.6, and 60.7 percent in Uruguay, Brazil, and Argentina, respectively, to 46.0, 25.2, and 19.1 percent in Mexico, Bolivia, and Peru, respectively (Table 2). Are contributory pensions progressive (equalizing) or regressive (unequalizing)? In Table 5 we compare the Gini coefficient pre-pensions (market income Gini for our sensitivity analysis) with the Gini coefficient post-pensions (market income Gini for the benchmark scenario). In Uruguay, Argentina, and Brazil pensions are equalizing. In Mexico and Peru they are slightly unequalizing. In Bolivia, their effect is neutral. This shows that a priori one cannot assert that contributory pensions in Latin America are systematically regressive as one frequently hears. In the cases of Mexico and Peru, the fact that they are unequalizing is particularly problematic because these countries' social security systems are partially funded by general government revenues. This implies that the subsidized portion of contributory pensions is regressive.

Pensions are also important for poverty reduction in Uruguay, Brazil, and Argentina. Their povertyreducing effect in Peru, Bolivia, and Mexico, however, is very small. These results are associated with the coverage of pensions among the elderly as well as the per capita size of the pensions. The results are also a consequence of the extent of informality. In Argentina, Brazil, and Uruguay the formal social security pension system covers a larger percent of the elderly population than in the other three countries. ${ }^{23}$

\footnotetext{
${ }^{23}$ Care should be taken in the interpretation of results in the case of Uruguay because due to the lack of adequate screening systems in the past, people who had never contributed (or not contributed enough) to the social security system received old-age pensions.
} 
TABLE 5. THE EFFECT OF CONTRIBUTORY PENSIONS ON INEQUALITY AND POVERTY: GINI AND POVERTY FOR PRE-PENSIONS AND POST-PENSIONS INCOME

\begin{tabular}{|c|c|c|c|c|c|c|}
\hline & $\begin{array}{l}\text { Argentina } \\
(2009)\end{array}$ & $\begin{array}{l}\text { Bolivia } \\
\text { (2009) }\end{array}$ & $\begin{array}{l}\text { Brazil } \\
(2009)\end{array}$ & $\begin{array}{l}\text { Mexico } \\
(2010)\end{array}$ & $\begin{array}{l}\text { Peru } \\
(2009)\end{array}$ & $\begin{array}{l}\text { Uruguay } \\
(2009)\end{array}$ \\
\hline Pensions as $\%$ GDP & 7.2 & 3.5 & 9.1 & 4.0 & 0.9 & 8.7 \\
\hline Gini pre-pensions & 0.506 & 0.503 & 0.600 & 0.509 & 0.503 & 0.527 \\
\hline Gini post-pensions & 0.489 & 0.503 & 0.579 & 0.511 & 0.504 & 0.492 \\
\hline Change in $\%$ & $-3.4 \%$ & $0.0 \%$ & $-3.5 \%$ & $0.4 \%$ & $0.3 \%$ & $-6.6 \%$ \\
\hline Headcount pre-pensions & 16.8 & 20.0 & 20.7 & 13.3 & 15.5 & 8.5 \\
\hline Headcount post-pensions & 13.0 & 19.6 & 15.1 & 12.6 & 15.2 & 5.1 \\
\hline Change in $\%$ & $-22.6 \%$ & $-2.0 \%$ & $-27.1 \%$ & $-5.3 \%$ & $-1.9 \%$ & $-40.0 \%$ \\
\hline
\end{tabular}

Sources: Argentina: Lustig and Pessino (forthcoming); Bolivia: Paz Arauco et al. (forthcoming); Brazil: Higgins and Pereira (forthcoming); Mexico: Scott (forthcoming); Peru: Jaramillo (forthcoming); and Uruguay: Bucheli et al. (forthcoming).

Note: Headcount in \% measured with international poverty line of US $\$ 2.50$ per day in purchasing power parity. For Argentina the pre-pensions Gini/Headcount is for net market income (market income minus personal income taxes and contributions to social security); for the rest, it is the Gini/Headcount for market income. For definitions and methodology see Lustig, Nora and Sean Higgins. 2013. Commitment to Equity Assessment (CEQ): Estimating the Incidence of Social Spending, Subsidies and Taxes. Handbook. CEQ WORKING PAPER NO. 1, Center for Inter-American Policy and Research and Department of Economics, Tulane University and Inter-American Dialogue, January.

\section{CONCLUSIONS}

The comparative analysis of the redistributive effects of the fiscal system presented here reveals more variations than a common Latin American welfare state.

Firstly, the Latin American states represented here vary significantly in size: total government spending ranges from 25.5 to 51.2 percent of GDP (35 percent on average) (Table 2).

Secondly, the countries vary in terms of the redistributive impact of their fiscal policy and this variation is not always correlated with size. The six fiscal systems analyzed can be divided into two groups in terms of their total redistributive effect (Figure 3). The first (Argentina, Brazil, and Uruguay) achieves a reduction of final income - that is, including the effect of in-kind transfers - inequality between 20 and 25 percent (and a reduction of disposable income poverty between 26 and 72 percent), while a second group (Peru, Bolivia, and Mexico) reduces final income inequality by 7.6 to 16 percent (and disposable income poverty by 7 to 15 percent) (Table 1). The less redistributive states are so either because they spend significantly less (Mexico and Peru) or because their spending is not targeted to the poor (Bolivia).

There are differences within as well as between these groups. Perhaps the most interesting finding is that 
equity may matter more than size. Bolivia achieves only half the inequality reduction of Argentina, despite spending 18 percent more on social transfers (analyzed) in relation to GDP (Table 2). More dramatically, the net effect of all taxes and cash transfers is to increase poverty by 3 percent in Bolivia, while in Uruguay with similar shares of cash transfers to GDP but significantly higher taxes, the net effect is to reduce poverty by 54 percent (Tables 1 and 2). However, this is also due in part to the fact that Uruguay has a higher GDP/capita than Bolivia; hence, the absolute amounts devoted to cash transfers will be higher and divided among fewer people (given that both the population and poverty rates in Uruguay are lower than in Bolivia). At the same time, with similar levels of redistributive effectiveness, the difference in redistributive effect between Mexico and Brazil is explained mostly by the differences in social spending levels. In the case of Peru, the amount of inequality reduction achieved is less than a third of inequality reduction in Brazil because not only is it slightly less effective but more importantly because social spending in Peru is just over a third of social spending in Brazil (analyzed) in relation to GDP (Figure 3).

The comparatively "rosy" redistributive picture of Argentina, Brazil, and Uruguay (by Latin American standards), however, hides some unpleasant facts. As discussed by Lustig and Pessino (forthcoming), the problems with Argentina's redistributive policies are mainly the allocation of nonsocial subsidies and fiscal sustainability. Total government spending on indirect subsidies equaled 5.6 percent of GDP in 2009 (incidence analysis did not include indirect subsidies), compared to the 3.7 percent of GDP spent on progressive cash transfers in 2009. These subsidies are primarily subsidies to agricultural producers, airlines, manufacturing, and transportation and energy. The first three are outright regressive (unequalizing) and their budget equaled 1.3 percent of GDP in 2009 (compared to 0.6 percent allocated to the Universal Family Allowance). In addition, Argentina's sharp rise in public spending during the $2000 \mathrm{~s}$ has been increasingly financed by distortionary taxes and unorthodox revenue-raising mechanisms. Moreover, the export tax-a major source of revenue-is highly sensitive to commodity prices. All in all, this points to the fact that the Argentine government has embarked on a redistribution process that - to some extent-generates unfair losses (to the formal sector retirees) and may not be fiscally sustainable unless subsidies accruing to the nonsocial sectors are significantly curbed.

In the case of Brazil, the most disturbing fact is the significant negative effect of consumption taxes on the poor. Based on the study by Higgins and Pereira (forthcoming), in Brazil 27 percent of the moderate poor are pushed down into extreme poverty and 4.5 percent of the extreme poor are pushed into ultra-poverty when comparing post-fiscal income poverty rates with respect to market income poverty rates. Also, consumption taxes more than offset the poverty-reducing effect of direct cash transfers (Figure 2) and the moderately poor are net-payers to the fiscal system (before imputing the value of in-kind transfers, that is).

In Brazil and Uruguay, spending on tertiary education is clearly "pro-rich." In Brazil 16.4 percent of the spending goes to the 4.7 percent of the population with market incomes above US $\$ 50$ PPP per day, while only 7.6 percent accrues to the 26.2 percent of the population that earns less than US $\$ 4$ PPP per day. The same is true for Uruguay: 14.5 percent of spending on tertiary education accrues to the 6.8 percent with market incomes above US\$50 PPP per day, while only 0.6 percent accrues to the 11.6 percent of the population that earns less than US\$4 PPP per day (Table 4). Thus, even though spending on tertiary education in Brazil and Uruguay is not unequalizing (it is progressive in relative terms), a large proportion subsidizes the children of the rich.

The impact of fiscal policy on inequality and poverty can be summarized as follows. Direct taxes and cash 
transfers reduce inequality and poverty by nontrivial amounts in Argentina, Brazil, and Uruguay but less so in Bolivia, Mexico, and Peru. While direct taxes are progressive, the redistributive impact is small because direct taxes as a share of GDP are generally low. Cash transfers are quite progressive in absolute terms, except in Bolivia where programs are not targeted to the poor. However, their poverty-reducing impact, as expected, is smaller in countries that spend less (as a share of GDP) on direct cash transfers targeted to the poor (Mexico and Peru). In Bolivia, Brazil, and Uruguay consumption taxes temper the redistributive impact of the fiscal system, and in Bolivia and Brazil, consumption taxes more than offset the povertyreducing impact of cash transfers.

When one includes the in-kind transfers in education and health, valued at government costs, they reduce inequality in all countries by considerably more than cash transfers. This result is not surprising given the much larger share of public spending devoted to education and health spending compared to cash transfers. Care should be taken, however, to read too much into the redistribution through transfers in-kind since the valuation using government costs may not reflect the actual valuation by the beneficiaries, and the method used to monetize the transfers in-kind does not take into account variations in quality. Furthermore, the progressiveness of the education and health systems could be due to an undesirable underlying phenomenon: that is, the middle-classes and the rich opting-out of the public education and public health systems because of quality concerns.

To put the results for these six Latin American countries in perspective, the average reduction in the disposable income Gini coefficient for advanced OECD countries equals 12 percentage points while the average for our six countries (which includes Argentina and Uruguay, possibly the most redistributive in the region) equals 3 percentage points. The average reduction in the final income Gini coefficient for OECD is 17 percentage points and for the six Latin American countries is 9 percentage points. Thus, in spite of the progress witnessed in terms of inequality and poverty reduction in the $2000 \mathrm{~s},{ }^{24}$ Latin America still lags behind significantly in terms of redistribution achieved through taxation and social spending.

${ }^{24}$ See, for example, Lopez-Calva and Lustig (2010). 


\section{REFERENCES}

Birdsall, Nancy, Augusto de la Torre, and Rachel Menezes. 2008. Fair Growth. Washington, D.C.: Center for Global Development and Inter-American Dialogue.

Birdsall, Nancy, Nora Lustig, and Christian Meyer. 2013. The New Poor in Latin America: Challenges and Risks. Center for Global Development Working Paper, forthcoming.

Breceda, Karla, Jamele Rigolini, and Jaime Saavedra. 2008. Latin America and the Social Contract: Patterns of Social Spending and Taxation. The World Bank Policy Research Working Paper, Washington, D.C.

Bucheli, Marisa, Nora Lustig, Máximo Rossi, and Florencia Amábile. Social Spending, Taxes, and Income Redistribution in Uruguay. In Lustig, Nora, Carola Pessino, and John Scott, editors, Fiscal Policy, Poverty and Redistribution in Latin America, Special Issue, Public Finance Review, forthcoming.

Ferreira, Francisco H. G., and Martin Ravallion. 2008. Global Poverty and Inequality: a Review of the Evidence. The World Bank Policy Research Working Paper Washington, D.C.

Ferreira, Francisco H. G, Julian Messina, Jamele Rigolini, Luis F. Lopez-Calva, Maria Ana Lugo, and Renos Vakis. 2013. Economic Mobility and the Rise of Latin American Middle Class. The World Bank: Washington, D.C.

Goñi, Edwin, J. Humberto López, and Luis Servén. 2011. Fiscal Redistribution and Income Inequality in Latin America. World Development 39(9): 1558-1569.

Higgins, Sean and Claudiney Pereira. The Effects of Brazil's High Taxation and Social Spending on the Distribution of Household Income. In Lustig, Nora, Carola Pessino, and John Scott, editors, Fiscal Policy, Poverty and Redistribution in Latin America, Special Issue, Public Finance Review, forthcoming.

Immervoll, Herwig, Horacio Levy, José Ricardo Nogueira, Cathal O’Donoghue, and Rozane Bezerra de Siqueira. 2009. The Impact of Brazil's Tax-Benefit System on Inequality and Poverty. In Poverty, Inequality, and Policy in Latin America, Stephan Klasen and Felicitas Nowak-Lehmann, eds., 271301. Cambridge, MA: MIT Press.

Inter-American Development Bank. 2011. Social Strategy for Equity and Productivity. Latin America and the Caribbean. Washington, D.C.: IDB.

Jaramillo, Miguel. The Incidence of Social Spending and Taxes in Peru. In Lustig, Nora, Carola Pessino, and John Scott, editors, Fiscal Policy, Poverty and Redistribution in Latin America, Special Issue, Public Finance Review, forthcoming.

Kakwani, Nanak C. 1977. Measurement of Tax Progressivity: An International Comparison. The Economic Journal 87(345): 71-80.

Lambert, Peter. 2002. The Distribution and Redistribution of Income (3rd edition). Manchester, UK: 
University of Manchester Press.

Lindert, Kathy, Emmanuel Skoufias, and Joseph Shapiro. 2006. Redistributing Income to the Poor and Rich: Public Transfers in Latin America and the Caribbean. The World Bank Social Protection Discussion Paper, Washington, D.C.

Lopez-Calva, Luis F. and Eduardo Ortiz-Juarez. 2011. A Vulnerability Approach to the Definition of the Middle Class. Policy Research Working Paper 5902, The World Bank, December, Washington, D.C.

Lopez-Calva, Luis F. And Nora Lustig. 2010. Declining Inequality in Latin America: A Decade of Progress?, Brookings Institution Press, Washington, DC and United Nations Development Programme (UNDP), New York.

Lustig, Nora, George Gray Molina, Sean Higgins, Wilson Jiménez, Veronica Paz, Claudiney Pereira, Carola Pessino, John Scott, and Ernesto Yáñez Aguilar. 2012. The Impact of Taxes and Social Spending on Inequality and Poverty in Argentina, Bolivia, Brazil, Mexico and Peru: A Synthesis of Results. Tulane University Economics Department and CIPR Working Paper, New Orleans, LA.

Lustig, Nora and Sean Higgins. 2013. Commitment to Equity Assessment (CEQ): Estimating the Incidence of Social Spending, Subsidies and Taxes. Handbook, CEQ Working Paper No. 1, July 2011; revised January 2013. New Orleans, LA.

Lustig, Nora and Sean Higgins. 2012. Fiscal Mobility and the Poor: A New Approach. Tulane Economics Department Working Paper 1202, New Orleans, Louisiana, April.

Lustig, Nora, Luis F. Lopez-Calva, and Eduardo Ortiz-Juarez. 2013. Declining Inequality in Latin America in the 2000s: The Cases of Argentina, Brazil, and Mexico, World Development, Vol. 44, pp. 129-141.

Lustig, Nora and Carola Pessino. Social Spending and Income Redistribution in Argentina in the 2000s: The Rising Role of Noncontributory Pensions. In Lustig, Nora, Carola Pessino, and John Scott, editors, Fiscal Policy, Poverty and Redistribution in Latin America, Special Issue, Public Finance Review, forthcoming.

Lustig, Nora, Carola Pessino, and John Scott, editors. Fiscal Policy, Poverty and Redistribution in Latin America, Special Issue, Public Finance Review, forthcoming.

Martinez-Vazquez, Jorge. 2008. The Impact of Budgets on the Poor: Tax and Expenditure Benefit Incidence Analysis, in Blanca Moreno-Dodson and Quentin Wodon, editors, Public Finance for Poverty Reduction Concepts and Case Studies from Africa and Latin America, Chapter 5. Washington, DC: World Bank.MDS (Ministério do Desenvolvimento Social e Combate à Fome). 2011. Relatorio de avaliação do plano plurianual, 2008-2011.

O’Donnell, Owen, Eddy van Doorslaer, Adam Wagstaff, and Magnus Lindelow. 2008. Analyzing Health Equity Using Household Survey Data: A Guide to Techniques and Their Implementation. Washington, D.C.: The World Bank.

OECD, Revenue statistics: Comparative tables, OECD Tax Statistics (database). 2013. http://www.oecd- 
ilibrary.org/taxation/taxes-on-personal-income_20758510-table4

Paz Arauco, Veronica, George Gray Molina, Wilson Jiménez Pozo, and Ernesto Yáñez Aguilar. Explaining Low Redistributive Impact in Bolivia. In Lustig, Nora, Carola Pessino, and John Scott, editors, Fiscal Policy, Poverty and Redistribution in Latin America, Special Issue, Public Finance Review, forthcoming.

SAGI (Secretaria de Avaliação e Gestão da Informação), and MDS (Ministério do Desenvolvimento Social). 2012. Ferramento de visualização dos dados. http://aplicacoes.mds.gov.br/sagi/miv/miv.php.

Scott, John. 2011. Gasto Público y Desarrollo Humano en México: Análisis de Incidencia y Equidad. UNDP Working Paper for Informe sobre Desarrollo Humano México 2011, Mexico City, Mexico.

Scott, John. Redistributive Impact and Efficiency of Mexico’s Fiscal System. In Lustig, Nora, Carola Pessino, and John Scott, editors, Fiscal Policy, Poverty and Redistribution in Latin America, Special Issue, Public Finance Review, forthcoming.

Silveira, Fernando Gaiger, Jonathan Ferreira, Joana Mostafa, and José Aparecido Carlos Ribeiro. 2011. Qual o Impacto da Tributação e dos Gastos Públicos Sociais na Distribuição de Renda do Brasil? Observando os Dois Lados da Moeda. In Progressividade da Tributação e Desoneração da Folha de Pagamentos Elementos para Reflexão, José Aparecido Carlos Ribeiro, Álvaro Luchiezi Jr., and Sérgio Eduardo Arbulu Mendonça, eds., 25-63, Brasilia: IPEA.

Wagstaff, Adam. 2012. Benefit-Incidence Analysis: Are Government Health Expenditures More Pro-Rich Than We Think? Health Economics 21: 351-366.

World Development Indicators, The World Bank. 2012. GNI per capita. http://data.worldbank.org/indicator/NY.GNP.PCAP.K 


\section{CEQ WORKING PAPER SERIES}

\section{WORKING PAPER NO. 1}

Lustig, Nora and Sean Higgins. 2013. Commitment to Equity Assessment (CEQ): Estimating the Incidence of Social Spending, Subsidies and Taxes. Handbook. CEQ Working Paper No. 1, Center for Inter-American Policy and Research and Department of Economics, Tulane University and Inter-American Dialogue, January.

\section{WORKING PAPER NO. 2}

Lustig, Nora. 2012. Commitment to Equity: Diagnostic Questionnaire. CEQ Working Paper No. 2, Center for Inter-American Policy and Research and Department of Economics, Tulane University and InterAmerican Dialogue, August.

WORKING PAPER NO. 3

Lustig, Nora and George Gray Molina, Sean Higgins, Miguel Jaramillo, Wilson Jiménez, Veronica Paz, Claudiney Pereira, Carola Pessino, John Scott, and Ernesto Yañez. 2012. The Impact of Taxes and Social Spending on Inequality and Poverty in Argentina, Bolivia,Brazil, Mexico and Peru: A Synthesis of Results. CEQ Working Paper No. 3, Center for Inter-American Policy and Research and Department of Economics, Tulane University and Inter-American Dialogue, August.

WORKING PAPER NO. 4

Lustig, Nora and Sean Higgins. 2012. Fiscal Incidence, Fiscal Mobility and the Poor: A New Approach. CEQ Working Paper No. 4, Center for Inter-American Policy and Research and Department of Economics, Tulane University and Inter-American Dialogue, September.

WORKING PAPER NO. 5

Lustig, Nora and Carola Pessino. 2013. Social Spending and Income Redistribution in Argentina in the 2000s: the Rising Role of Noncontributory Pensions. CEQ Working Paper No. 5, Center for Inter-American Policy and Research and Department of Economics, Tulane University and Inter-American Dialogue, REVISED July 2013.

WORKING PAPER NO. 6

Paz Arauco, Verónica, George Gray Molina, Wilson Jiménez Pozo, and Ernesto Yáñez Aguilar. 2013. Explaining Low Redistributive Impact in Bolivia. CEQ Working Paper No. 6, Center for Inter-American Policy and Research and Department of Economics, Tulane University and Inter-American Dialogue, January.

WORKING PAPER NO. 7

Higgins, Sean and Claudiney Pereira. 2013. The Effects of Brazil's High Taxation and Social Spending on the Distribution of Housebold Income. CEQ Working Paper No. 7, Center for Inter-American Policy and Research and Department of Economics, Tulane University and Inter-American Dialogue, January.

WORKING PAPER NO. 8

Scott, John. 2013. Redistributive Impact and Efficiency of Mexico's Fiscal System. CEQ Working Paper No. 8, Center for Inter-American Policy and Research and Department of Economics, Tulane University and Inter-American Dialogue, January.

WORKING PAPER NO. 9

Jaramillo Baanante, Miguel. 2013. The Incidence of Social Spending and Taxes in Peru. CEQ Working Paper No. 9, Center for Inter-American Policy and Research and Department of Economics, Tulane University and Inter-American Dialogue, January.

WORKING PAPER NO. 10

Bucheli, Marisa and Nora Lustig, Máximo Rossi and Florencia Amábile. 2013. Social Spending, Taxes, and 
Income Redistribution in Uruguay. CEQ Working Paper No. 10, Center for Inter-American Policy and Research and Department of Economics, Tulane University and Inter-American Dialogue, January.

WORKING PAPER NO. 11

Higgins, Sean and Nora Lustig, Julio Ramirez and Billy Swanson. Social Spending, Taxes and Income Redistribution in Paraguay. CEQ Working Paper No. 11, Center for Inter-American Policy and Research and Department of Economics, Tulane University and Inter-American Dialogue, February.

WORKING PAPER NO. 12

Alvaredo, Facundo and Juliana Londoño Vélez. 2013. High Incomes and Personal Taxation in a Developing Economy: Colombia 1993-2010. CEQ Working Paper No. 12, Center for Inter-American Policy and Research and Department of Economics, Tulane University and Inter-American Dialogue, March.

WORKING PAPER NO. 13

Lustig, Nora, and Carola Pessino and John Scott. 2013. The Impact of Taxes and Social Spending on Inequality and Poverty in Argentina, Bolivia, Brazil, Mexico, Peru and Uruguay: An Overview. CEQ Working Paper No. 13, Center for Inter-American Policy and Research and Department of Economics, Tulane University and Inter-American Dialogue, April, REVISED August 2013.

WORKING PAPER NO. 14

Higgins, Sean and Nora Lustig. 2013. Measuring Impoverishment: An Overlooked Dimension of Fiscal Incidence. CEQ Working Paper No. 14, Center for Inter-American Policy and Research and Department of Economics, Tulane University and Inter-American Dialogue, April.

WORKING PAPER NO. 15

Tanzi, Vito. 2013. Tax Reform in Latin America: A long term assessment. CEQ Working Paper No. 15, Center for Inter-American Policy and Research and Department of Economics, Tulane University and InterAmerican Dialogue, April. 


\section{WHAT IS CEQ?}

Led by Nora Lustig (Tulane University) and Peter Hakim (Inter-American Dialogue), the Commitment to Equity (CEQ) project is designed to analyze the impact of taxes and social spending on inequality and poverty, and to provide a roadmap for governments, multilateral institutions, and nongovernmental organizations in their efforts to build more equitable societies. CEQ/Latin America is a joint project of the Inter-American Dialogue (IAD) and Tulane University's Center for Inter-American Policy and Research (CIPR) and Department of Economics. The project has received financial support from the Canadian International Development Agency (CIDA), the Development Bank of Latin America (CAF), the General Electric Foundation, the Inter-American Development Bank (LADB), the International Fund for Agricultural Development (IFAD), the Norwegian Ministry of Foreign Aftairs, the United Nations Development Programme's Regional Bureau for Latin America and the Caribbean (UNDP/RBLAC), and the World Bank. hrtp://ermmitmenttoequity.r.g 